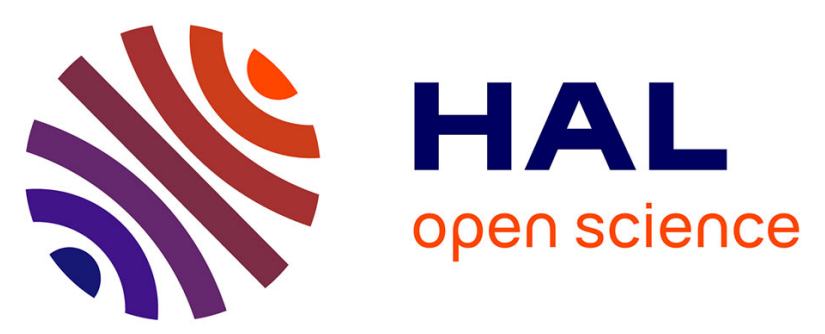

\title{
Synthesis and Characterization of Neutral and Cationic Magnesium Complexes Supported by NHC Ligands
}

\author{
Jean-Charles Bruyere, Christophe Gourlaouen, Lydia Karmazin, Corinne \\ Bailly, Corinne Boudon, Laurent Ruhlmann, Pierre de Frémont, Samuel \\ Dagorne
}

\section{To cite this version:}

Jean-Charles Bruyere, Christophe Gourlaouen, Lydia Karmazin, Corinne Bailly, Corinne Boudon, et al.. Synthesis and Characterization of Neutral and Cationic Magnesium Complexes Supported by NHC Ligands. Organometallics, 2019, 38 (14), pp.2748-2757. 10.1021/acs.organomet.9b00304 . hal-02324082

\section{HAL Id: hal-02324082 \\ https://hal.science/hal-02324082}

Submitted on 4 Feb 2022

HAL is a multi-disciplinary open access archive for the deposit and dissemination of scientific research documents, whether they are published or not. The documents may come from teaching and research institutions in France or abroad, or from public or private research centers.
L'archive ouverte pluridisciplinaire HAL, est destinée au dépôt et à la diffusion de documents scientifiques de niveau recherche, publiés ou non, émanant des établissements d'enseignement et de recherche français ou étrangers, des laboratoires publics ou privés. 


\section{Synthesis and Characterization of Neutral and Cationic Magnesium Complexes Supported by NHC Ligands}

Jean-Charles Bruyere, ${ }^{\dagger}$ Christophe Gourlaouen, ${ }^{\dagger}$ Lydia Karmazin, ${ }^{\ddagger}$ Corinne Bailly ${ }^{\star}$ Corinne Boudon, ${ }^{\dagger}$ Laurent Ruhlmann, ${ }^{\dagger}$ Pierre de Frémont, ${ }^{\dagger *}$ and Samuel Dagorne ${ }^{\dagger *}$

${ }^{\dagger}$ Institut de Chimie de Strasbourg, CNRS - Université de Strasbourg, 1 rue Blaise Pascal, 67000 Strasbourg, France.

$\$$ Service de Radiocristallographie - Fédération de Chimie Le Bel FR2010 - 1, rue Blaise Pascal - BP296/R8 - 67008 Strasbourg Cedex - France.

\section{RECEIVED DATE}


For Table of Contents Only (Graphical Abstract)

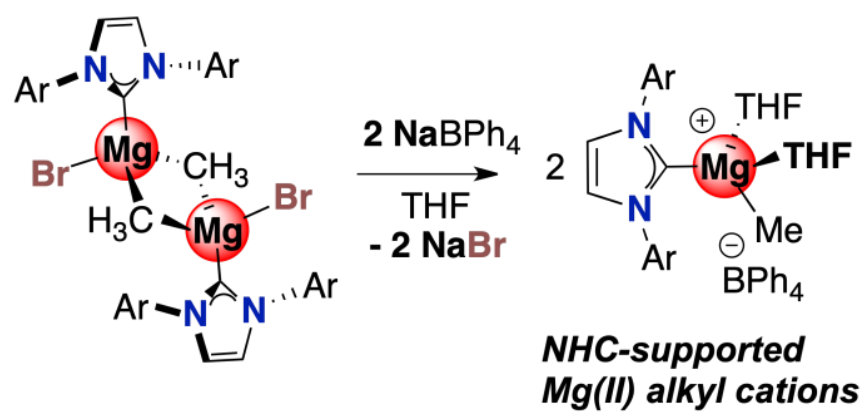




\begin{abstract}
A series of neutral N-heterocyclic carbene (NHC) magnesium alkyl complexes was synthesized by reaction of IMes (IMes = 1,3-bis(2,4,6-trimethylphenyl)imidazol-2-ylidene) and IPr (IPr = 1,3-bis(2,6-diisopropylphenyl)imidazol-2-ylidene) with Grignard reagents. In the presence of THF, mononuclear species $[\mathrm{Mg}(\mathrm{IMes})(\mathrm{R})(\mathrm{Br})(\mathrm{THF})](\mathbf{1}, \quad \mathrm{R}=\mathrm{Me} ; \mathbf{2}, \mathrm{R}=\mathrm{Et})$ and $[\mathrm{Mg}(\operatorname{IPr})(\mathrm{R})(\mathrm{Br})(\mathrm{THF})](\mathbf{3}, \mathrm{R}=\mathrm{Me} ; \mathbf{4}, \mathrm{R}=\mathrm{Et})$ were isolated. Complex 4 was further methylated to afford the $\mathrm{Mg}-\mathrm{THF}$ adduct $\left[\mathrm{Mg}(\mathrm{IPr})(\mathrm{Me})_{2}(\mathrm{THF})\right]$ (5) which crystallizes as dimer $\left[\left\{(\operatorname{Mg}(\operatorname{IPr})(\mathrm{Me})\}_{2}(\mu-\mathrm{Me})_{2}\right]\left(\mathbf{5}^{\prime}\right)\right.$, thus evidencing the labile THF coordination in these systems. In contrast, in the presence of $\mathrm{Et}_{2} \mathrm{O}$, dinuclear $\mathrm{Mg}(\mathrm{II})$ species $\left[\left\{(\mathrm{Mg}(\mathrm{NHC})(\mathrm{Br})\}_{2}(\mu-\mathrm{Me})_{2}\right](\mathbf{6}, \mathrm{NHC}\right.$ $=\mathrm{IMes} ; \mathbf{7}, \mathrm{NHC}=\mathrm{IPr}),\left[\left\{(\mathrm{Mg}(\mathrm{IMes})(\mathrm{Ph})\}_{2}(\mu-\mathrm{Br})_{2}\right](\mathbf{8}),\left[\left\{\left(\mathrm{Mg}(\mathrm{IMes})\left(\mathrm{CH}_{2} \mathrm{Ph}\right)\right\}_{2}(\mu-\mathrm{Cl})_{2}\right](\mathbf{9})\right.\right.$ and $\left[\left\{(\mathrm{Mg}(\mathrm{IPr})(\mathrm{Ph})\}_{2}(\mu-\mathrm{Br})_{2}\right] \quad(\mathbf{1 0})\right.$ were isolated and characterized. The protonolysis reaction between protio-ligand [IMes- $\mathrm{H}] \mathrm{Cl}$ and $\mathrm{EtMgBr}$ afforded the $\mathrm{Mg}(\mathrm{II})$ dihalido dimer $\left[\left\{(\mathrm{Mg}(\mathrm{IMes})(\mathrm{Br})\}_{2}(\mu-\mathrm{Cl})_{2}\right](\mathbf{1 1})\right.$. The solid state molecular structures of species 5', 6-11 were established through X-ray crystallographic studies. THF adducts $\mathbf{1}$ and $\mathbf{3}$ may be readily ionized by a salt metathesis reaction with $\left[\mathrm{BPh}_{4}\right] \mathrm{Na}$ in the presence of THF to yield NHC-supported $\mathrm{Mg}(\mathrm{II})$ alkyl cations $\left[\left\{\mathrm{Mg}(\mathrm{NHC})(\mathrm{Me})(\mathrm{THF})_{2}\right\}\right]^{+}(\mathbf{1 2}, \mathrm{NHC}=\mathrm{IMes} ; \mathbf{1 3}, \mathrm{NHC}=\mathrm{IPr})$ as $\mathrm{BPh}_{4}{ }^{-}$ salts. Reflecting the labile THF coordination to $\mathrm{Mg}(\mathrm{II})$ in these cations, mononuclear cation 12 crystallizes as di-cation $\left[\left\{(\mathrm{Mg}(\mathrm{IMes})(\mathrm{THF})\}_{2}(\mu-\mathrm{Me})_{2}\right]^{2+}(\mathbf{1 2}\right.$ '). Only partial ionization of the halido methyl dimer 6 was observed by reaction with $\left[\mathrm{B}\left(\mathrm{C}_{6} \mathrm{~F}_{5}\right)_{4}\right] \mathrm{Li}$ in $\mathrm{PhBr}$ to afford tetranuclear $\mathrm{NHC}-\mathrm{Mg}(\mathrm{II})$ di-cationic aggregate $\left.\left[\{[\mathrm{Mg}(\mathrm{IMes})(\mathrm{Me})][\mathrm{Mg}(\mathrm{IMes})]\}(\mu-\mathrm{Me})_{2}\right]_{2}(\mu-\mathrm{Br})_{2}\right]^{2+}(\mathbf{1 4})$ as a $\mathrm{B}\left(\mathrm{C}_{6} \mathrm{~F}_{5}\right)_{4}$ salt. Computational studies were performed for selected neutral and cationic NHC$\mathrm{Mg}(\mathrm{II})$ derivatives and all agree with the electronic structure and bonding at $\mathrm{Mg}$ (II) being largely dominated by electrostatic interactions.
\end{abstract}




\section{Introduction}

In 1900, Grignard described the synthesis of the ubiquitous and eponymous organomagnesium halide reagents. ${ }^{1}$ Alkyl/aryllithium and alkyl/arylmagnesium species are since then widely used reagents in organic synthesis, essentially as alkylating and arylating stoichiometric reagents or co-catalysts. ${ }^{3,4}$ Besides protolytic sensitivity, the preparation of welldefined organometallic complexes of $\mathrm{Mg}(\mathrm{II})$ is frequently complicated by ligand redistribution reactions in solution, also known as Schlenk equilibrium, due to their rather labile coordination of most monodentate ligands to $\mathrm{Mg}(\mathrm{II}){ }^{2,3}$ Thanks to their exceptional $\sigma$-donating properties, $\mathrm{N}$ heterocyclic carbene ligands are of interest for the stabilization of various metal centers, leading to NHC-supported organometallics with improved stability that have found various applications across chemical science. ${ }^{4}$ Though NHCs may stabilize oxophilic and electrophilic metal centers, ${ }^{5}$ the $\mathrm{M}-\mathrm{NHC}$ bond in such entities becomes increasingly labile with the electropositivity of the metal centers, which may significantly limit their stability and well-defined nature. Certainly related to the latter, the organometallic chemistry of NHC complexes of group $s$ metals remains relatively unexplored compared to other main group metal/heteroatoms. ${ }^{5,6}$ In particular, NHC magnesium complexes, first reported in 1993 by Arduengo, ${ }^{7}$ have undergone a limited development, with an average of roughly a publication per year over the past 25 years. ${ }^{5,8}$ With a monodentate NHC ligand, only a few examples of $\mathrm{Mg}-\mathrm{NHC}$ adducts of the type $(\mathrm{NHC}) \mathrm{Mg}(\mathrm{X})\left(\mathrm{X}^{\prime}\right)_{2},\left[(\mathrm{NHC}) \mathrm{Mg}-\mathrm{X}^{\prime}\right]_{2}\left(\mathrm{X}, \mathrm{X}^{\prime}=\right.$ alkyl, halide $)$ as well as a couple of NHCsupported $\mathrm{Mg}(\mathrm{II})$ amido/hydrido species are thus far known. ${ }^{8}$ Yet, from a general point of view, well-defined $\mathrm{Mg}(\mathrm{II})$ organometallics, which are thus based on an inexpensive and non-toxic metal center, are of potential interest for various stoichiometric and catalytic transformations of current importance. ${ }^{8 \mathrm{~b}, 8 \mathrm{~g}, 9,10,11}$

Well-defined $\mathrm{Mg}(\mathrm{II})$ organocations, which are typically supported by $N$-based multidentate ligand, are currently attracting attention as highly electrophilic and Lewis acidic $\mathrm{Mg}$ (II) species able to activate various unsaturated small molecules, including arenes, mediate

unusual chemical transformations and be of potential interest in Lewis acid catalysis. ${ }^{12}$ Following our earlier studies on NHC-stabilized Zn(II) organocations, which showed the ability of NHCs to stabilize two-coordinate $\mathrm{Zn}$ (II) cationic alkyls/aryls, ${ }^{13}$ we became interested into probing the suitability of NHCs to access stable and robust NHC-stabilized $\mathrm{Mg}$ (II) organocations, a class of species unknown thus far. Along the way, a variety of NHC-stabilized Grignard reagents, used as 
neutral precursors, were characterized allowing the establishment of structural trends. In the present contribution, we describe the synthesis and structural characterization of a variety of neutral NHC magnesium supported by halide- and alkyl/phenyl/benzyl-ligands. Some of these neutral precursors were then successfully ionized to NHC-stabilized $\mathrm{Mg}(\mathrm{II})$-alkyl cations. The electronic structures of selected neutral and cationic complexes, as estimated from DFT calculations, complement their structural characterization.

\section{Results and discussion}

Synthesis and Structure of Neutral NHC-supported Mg(II) complexes 1-11. A diverse set of NHC-supported $\mathrm{Mg}$-alkyl/aryl/benzyl halides were targeted to gain structural insights on such compounds prior to their subsequent ionization. The addition of an ethereal solution of ethylmagnesium bromide or methylmagnesium bromide to a THF solution of IMes (IMes $=$ 1,3-bis(2,4,6-trimethylphenyl)imidazol-2-ylidene) $\quad$ or $\quad \operatorname{IPr} \quad(\operatorname{IPr}=1,3$-bis(2,6diisopropylphenyl)imidazol-2-ylidene) afforded complexes $[\mathrm{Mg}(\mathrm{IMes})(\mathrm{Et})(\mathrm{Br})(\mathrm{THF})] \quad$ (1), [Mg(IMes)(Me)(Br)(THF)] (2), [Mg(IPr)(Et)(Br)(THF)] (3), or [Mg(IPr)(Me)(Br)(THF)] (4), in

excellent yields (Scheme 1). ${ }^{13} \mathrm{C}$ NMR data confirmed the formation of $\mathrm{Mg}(\mathrm{II})-\mathrm{NHC}$ bonds with $\mathrm{C}_{\text {carbene }}$ chemical shifts comprised between 185 and $190 \mathrm{ppm}^{8}{ }^{8}$ The persistence of $\mathrm{Mg}(\mathrm{II})-\mathrm{alkyl}$ bonds was confirmed by ${ }^{1} \mathrm{H}$ NMR spectroscopy (with high field signals ranging from -1.18 to $2.03 \mathrm{ppm}$ ). NMR data also agree with the coordination of a THF molecule per $\mathrm{Mg}(\mathrm{II})$ center. Complexes 1-4 are poorly soluble in benzene, toluene, or dichloromethane, but soluble and stable for weeks in THF at room temperature. Unfortunately, all attempts to crystallize THF adducts 1-4 remained unsuccessful.

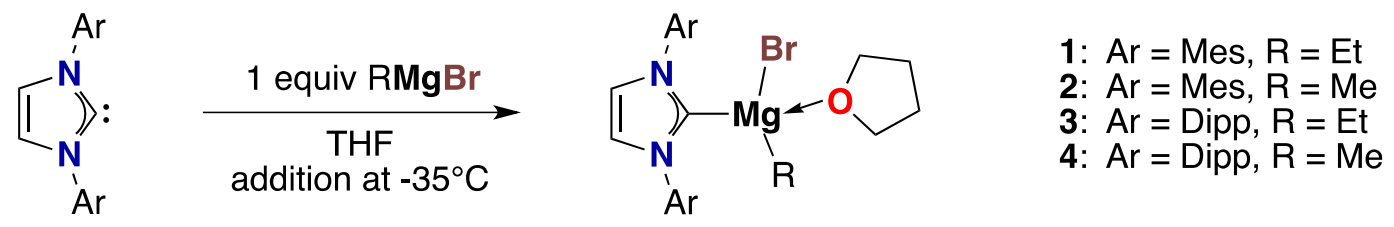

Scheme 1. Synthesis of the Mg complexes 1-4

Species $[\mathrm{Mg}(\mathrm{IPr})(\mathrm{Me})(\mathrm{Br})(\mathrm{THF})]$ (4) was further methylated by reaction with methyllithium (THF, $-35^{\circ} \mathrm{C}$ ) to form the corresponding dimethyl complex $\left[\mathrm{Mg}(\operatorname{IPr})(\mathrm{Me})_{2}(\mathrm{THF})\right]$ 
(5, Scheme 2) in good yield (75\%), as deduced from NMR data. In particular, the ${ }^{1} \mathrm{H}$ NMR spectrum for 5 displays a characteristic signal at $-1.93 \mathrm{ppm}$ associated with the $\mathrm{Mg} \mathrm{Me}_{2}$ moiety and resonances consistent with the coordination of a THF molecule. However, as determined by SC-XRD studies, species 5 crystallizes (from THF/pentane) as THF-free dimeric complex $\left[\left\{(\operatorname{Mg}(\operatorname{IPr})(\mathrm{Me})\}_{2}(\mu-\mathrm{Me})_{2}\right]\left(\mathbf{5}^{\prime}\right.\right.$, Figure 1$)$, clearly indicating a labile THF coordination in parent complex $\mathbf{5}$ as also observed in a recent study on dihalido $(\mathrm{NHC}) \mathrm{MgX}_{2}$ species. ${ }^{8 \mathrm{~h}}$ Dimer $\mathbf{5}$, features two NHC magnesium fragments linked by two $\mu$-Me bridges. The two $\mathrm{Mg}$ (II) cations adopt a tetrahedral coordination geometry and the $\mathrm{Mg} 1{ }^{\cdots} \mathrm{Mg} 1$ ' distance $(2.7539(11) \AA$ ) is

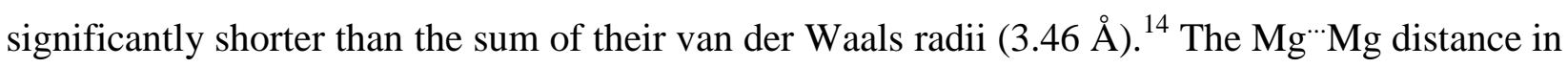
$\mathbf{5}^{\prime}$ is also intriguingly smaller than the $\mathrm{Mg}-\mathrm{Mg}$ bond distances observed in $\mathrm{Mg}(\mathrm{I})$ dimers [(BDI)$\mathrm{Mg}-\mathrm{Mg}(\mathrm{BDI})]\left(\mathrm{BDI}=N, N \beta\right.$-diketiminate), which range from 2.81(2) to 2.8656(2) $\AA .^{15}$ The $\mathrm{Mg}-(\mu-\mathrm{Me})$ bond distances $(2.256(2)$ and 2.262(3) $\AA$ ) are substantially longer than those of terminal $\mathrm{Mg}-\mathrm{Me}$ bonds (2.141(2) $\AA$ ). All geometrical parameters of 5' are similar to those reported for the bridged dinuclear complex $\left[\left\{(\mathrm{Mg}(\mathrm{IPr})(\mathrm{Et})\}_{2}(\mu-\mathrm{Et})_{2}\right]\right.$ by Arduengo et. al. ${ }^{7}$

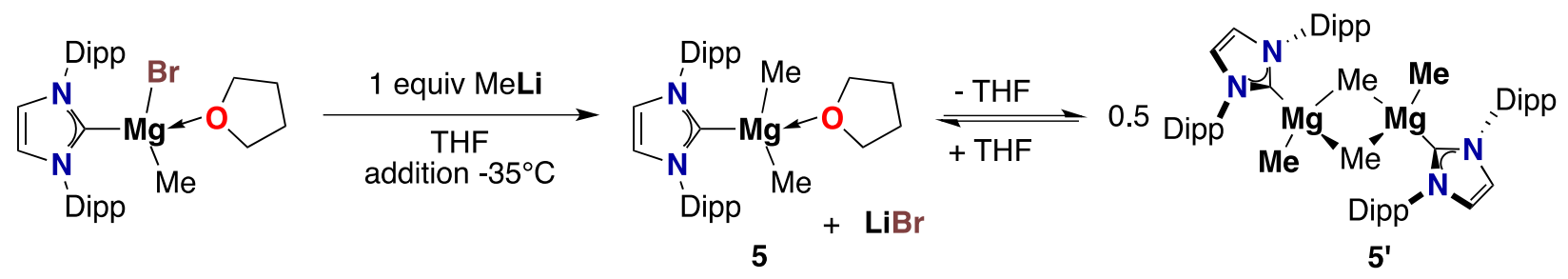

Scheme 2. Synthesis of THF adduct 5 and dimer 5, 


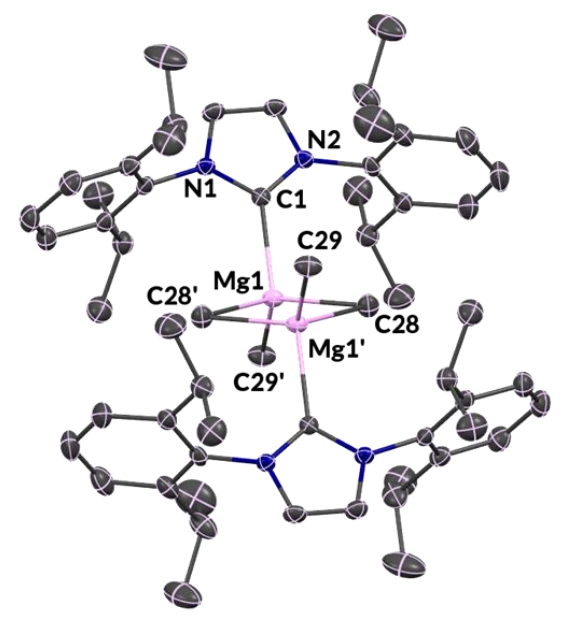

Figure 1. ORTEP representation of 5' (30\% probability). Hydrogen atoms have been omitted for clarity. Selected bond distances $(\AA)$ and angles $\left(^{\circ}\right)$ : Mg1-C1 2.276(2), Mg1-C28 2.256(2), Mg1-C28' 2.263(2), Mg1-C29 2.141(2), C1-Mg1-C28 107.85(8), C1-Mg1-C28' 108.37(8), $\mathrm{C} 1-\mathrm{Mg} 1-\mathrm{C} 29 \quad 105.74(7), \quad \mathrm{C} 28-\mathrm{Mg} 1-\mathrm{C} 28, \quad 104.89(7), \quad \mathrm{C} 28-\mathrm{Mg} 1-\mathrm{C} 29$ 115.10(9), $\mathrm{C} 28^{\prime}-\mathrm{Mg} 1-\mathrm{C} 29$ 114.61(9).

In the absence of THF, the stoichiometric reaction of $\mathrm{MeMgBr}\left(\mathrm{Et}_{2} \mathrm{O}\right.$ solution) with carbenes IMes and IPr (in toluene) led to the formation of dimeric complexes $\left[\left\{(\mathrm{Mg}(\mathrm{IMes})(\mathrm{Br})\}_{2}(\mu-\mathrm{Me})_{2}\right](\mathbf{6}),\left[\left\{(\mathrm{Mg}(\mathrm{IPr})(\mathrm{Br})\}_{2}(\mu-\mathrm{Me})_{2}\right]\right.\right.$ (7) in good yields (Scheme 3), highlighting the key role of THF for the isolation of mononuclear NHC-Mg species 1-4. For instance, the NMR data for 6 and $7\left(\mathrm{C}_{6} \mathrm{D}_{5} \mathrm{Br}, \mathrm{RT}\right)$ confirm the presence of $\mathrm{Mg}-\mathrm{Me}$ group with a ${ }^{1} \mathrm{H}$ NMR singlet at $-1.96 \mathrm{ppm}$, and a ${ }^{13} \mathrm{C}$ NMR $\mathrm{C}_{\text {carbene }}$ signal at $182.0 \mathrm{ppm}$ in line with coordination to $\mathrm{Mg}(\mathrm{II})$. In the case of species $6,{ }^{1} \mathrm{H}$ DOSY NMR data agree with a dimeric structure in solution under the studied conditions $\left(\mathrm{C}_{6} \mathrm{D}_{5} \mathrm{Br}, \mathrm{RT}\right)$. The hydrodynamic volume of 6 was estimated to be $1125 \AA^{3}$, which is close to the volume of dimeric 6 in the solid state (1150 $\AA^{3}$ ) as estimated from SC-XRD data (vide infra). Both complexes 6 and 7 crystallize from toluene/pentane as dimers comprising two NHC magnesium fragments surprisingly linked by two bridging $\mu$-Me groups instead of $\mu$ - $\mathrm{Br}$ bridges as would be expected (Figure 2 for complex 6 ). Thus, a terminal $\mathrm{Mg}-\mathrm{Br}$ completes the coordination sphere of each $\mathrm{Mg}$ (II) center. $\mathrm{The} \mathrm{Mg}-\mathrm{C}$ and $\mathrm{Mg}$-halide bond lengths are in agreement with those found in the literature, ${ }^{20}$ such as species $\left[\left\{(\operatorname{Mg}(\operatorname{IPr})(\mathrm{I})\}_{2}(\mu-\mathrm{I})_{2}\right]\right.$ and $\left[\left\{(\mathrm{Mg}(\operatorname{IPr})(\mathrm{Cl})\}_{2}(\mu-\mathrm{Cl})_{2}\right]\right.$ recently reported. ${ }^{8 \mathrm{f}, 8 \mathrm{~h}}$ The structures of $\mathbf{6}$ and 
7 highlight the preferential bridging of $\mathrm{Me} v$ s. halide groups and show that $\mathrm{Et}_{2} \mathrm{O}$ does not dissociate dimers $\mathbf{6}$ and 7, even though a magnesium dihalide complex supported by an abnormal NHC and an ether molecule is known. ${ }^{\text {sh }}$ Similar to $\mathbf{5}^{\prime}$, the distance between the $\mathrm{Mg}$ (II) centers in 6 is equal to 2.750(4) A. Alternatively, complex 6 was also prepared with a moderate yield (32 \%) via reaction of 1 equiv of IMes with $\mathrm{MgCl}_{2}$ followed by methylation with 1 equiv of MeLi.

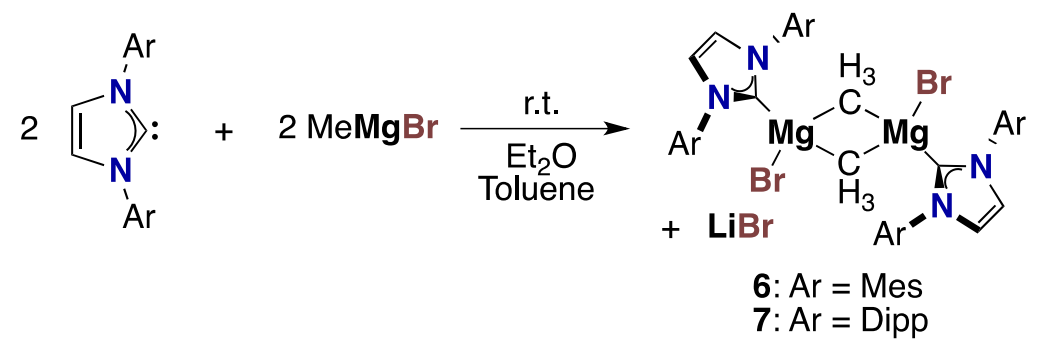

Scheme 3. Synthesis of species 6 and 7

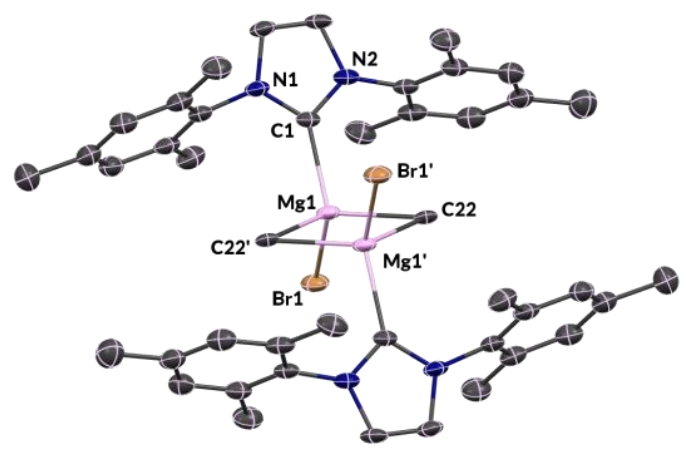

Figure 2. ORTEP representation of 6 (30\% probability). Hydrogen atoms have been omitted for clarity. Selected bond distances $(\AA)$ and angles $\left({ }^{\circ}\right)$ : Mg1-C1 2.214(6), Mg1-C22 2.313(6), Mg1-C22’ 2.325(6), Mg1-Br1 2.4588(19), C1-Mg1-C22 108.8(2), C1-Mg1-C22' 108.7(2), $\mathrm{C} 1-\mathrm{Mg} 1-\mathrm{Br} 1 \quad 112.63(17), \quad \mathrm{C} 22-\mathrm{Mg} 1-\mathrm{Br} 1 \quad 109.58(15), \quad \mathrm{C} 22{ }^{\prime}-\mathrm{Mg} 1-\mathrm{Br} 1 \quad$ 109.76(15), C22-Mg1-C22' 107.27(18).

To gain further knowledge on the structural trends of $\mathrm{NHC}-\mathrm{Mg}(\mathrm{R})(\mathrm{X})$ species, the coordination of IMes and IPr was extended other classical Grignard reagents such as phenylmagnesium bromide, benzylmagnesium chloride. Thus, dimeric complexes $\left[\left\{(\mathrm{Mg}(\mathrm{IMes})(\mathrm{Ph})\}_{2}(\mu-\mathrm{Br})_{2}\right](\mathbf{8}),\left[\left\{(\mathrm{Mg}(\mathrm{IMes})(\mathrm{Bn})\}_{2}(\mu-\mathrm{Cl})_{2}\right](\mathbf{9})\right.\right.$ and $\left[\left\{(\mathrm{Mg}(\mathrm{IPr})(\mathrm{Ph})\}_{2}(\mu-\mathrm{Br})_{2}\right]\right.$ 
(10) were prepared in good yields (65-85\%) upon combining a 1/1 mixture of the corresponding carbene and $\mathrm{RMgX}$ precursor in $\mathrm{Et}_{2} \mathrm{O} /$ toluene. The molecular structures of species 8-10 were determined by SC-XRD establishing their dimeric nature in the solid state (Figure 3). Thus, unlike NHC-Mg(II) methyl halides dimers 6 and 7, which contain two $\mathrm{Mg}-(\mu-M e)$ groups, species 8-10 preferentially form $\mu$-X halide bridges with the phenyl/benzyl groups as terminal ligands. Other bonding and geometrical parameters are similar to those observed for species $\mathbf{6}$ and 7. The NMR data for species 8-10 are consistent with the proposed formulations.
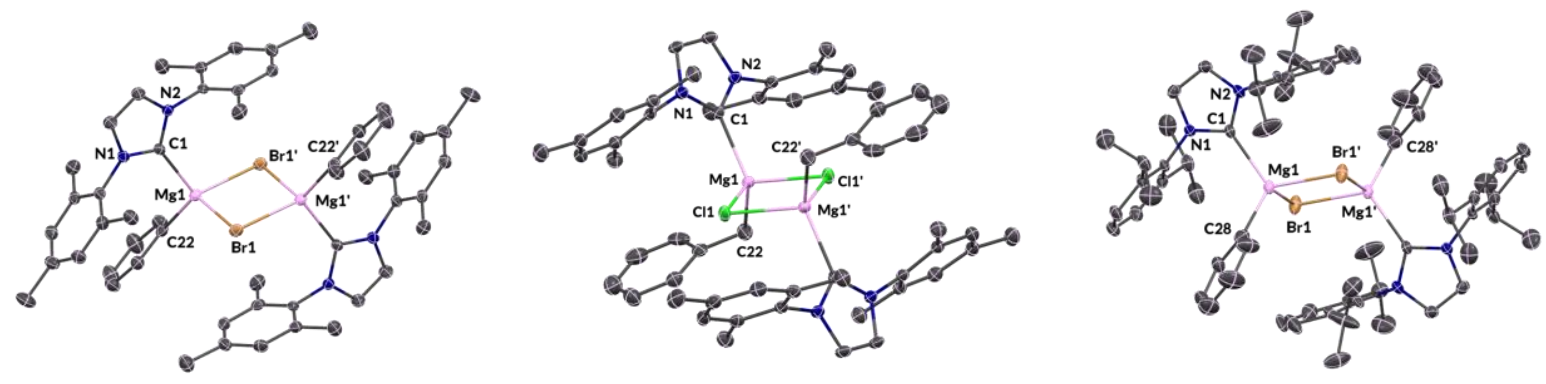

Figure 3: ORTEP representations of $\mathbf{8 , 9}$ and $\mathbf{1 0}$ (30\% probability). Hydrogen atoms, and cocrystallized benzene for $\mathbf{8}$, have been omitted for clarity. Selected bond distances $(\AA)$ and angles $\left(^{\circ}\right)$ : for 8: $\mathrm{Mg} 1-\mathrm{C} 1$ 2.225(4), $\mathrm{Mg} 1-\mathrm{C} 22$ 2.129(4), Mg1-Br1 2.5842(15), C1-Mg1-C22 115.07(15), C1-Mg1-Br1 112.38(11), C22-Mg1-Br1 112.55(12), Br1-Mg1-Br1' 92.57(4); for 9: $\mathrm{Mg} 1-\mathrm{C} 1$ 2.2065(15), Mg1-C22 2.1411(19), Mg1-Cl1 2.4224(7), Mg1-Cl1' 2.4341(7), C1-Mg1-C22 122.29(8), C1-Mg1-Cl1 107.77(4), C1-Mg1-Cl1' 109.20(4), C22-Mg1-Cl1 112.79(7), C22-Mg1-Cl1' 108.28(6), Cl1-Mg1-Cl1' 92.38(2); for 10: Mg1-C1 2.216(2), Mg1-C28 2.280(2), Mg1-C28' 2.272(2), Mg1-Br1 2.4562(8), C1-Mg1-C28 112.48(8), C1-Mg1-C28' 112.36(8), C1-Mg1-Br1 105.91(6), C28-Mg1-Br1 110.15(6), C28'-Mg1-Br1 109.36(6), C28-Mg1-C28' 106.59(7).

Though NHC-Mg species are typically prepared from free NHC and $\mathrm{Mg}$ (II) precursors, they may directly be prepared through protonolysis of the imidazolium salts. ${ }^{8 \mathrm{f}}$ Thus, protio ligand IMesHCl (1,3-bis(2,4,6-trimethylphenyl)imidazolium chloride) immediately reacts with 1 equiv $\mathrm{EtMgBr}\left(\mathrm{THF} / \mathrm{Et}_{2} \mathrm{O}, 2 \mathrm{~h}\right.$, RT) through ethane elimination to afford dinuclear complex $\left[\left\{(\mathrm{Mg}(\mathrm{IMes})(\mathrm{Br})\}_{2}(\mu-\mathrm{Cl})_{2}\right](\mathbf{1 1}\right.$, Scheme 4$)$ in high yield $(85 \%)$, as deduced from NMR and SCXRD data. ${ }^{1} \mathrm{H}$ and ${ }^{13} \mathrm{C}$ NMR spectra confirm the formation of 11, with the absence of the azolium proton signal, the presence of a ${ }^{13} \mathrm{C}$ NMR $C_{\text {carbene }} \operatorname{signal}(\delta=187.0 \mathrm{ppm})$ and no THF moiety. In 
the solid state, species 11 (Figure 4) is a dimer featuring two NHC magnesium fragments connected by two $\mathrm{Mg}-(\mu-\mathrm{Cl})-\mathrm{Mg}$ bridges, with bonding parameters in agreement with those found in the literature, particularly with complexes $\left[\left\{(\operatorname{Mg}(\operatorname{IPr})(\mathrm{I})\}_{2}(\mu-\mathrm{I})_{2}\right]\right.$ and $\left[\left\{(\mathrm{Mg}(\mathrm{IPr})(\mathrm{Cl})\}_{2}(\mu-\mathrm{Cl})_{2}\right]\right.$ recently reported. ${ }^{8 \mathrm{~g}, 8 \mathrm{~h}}$

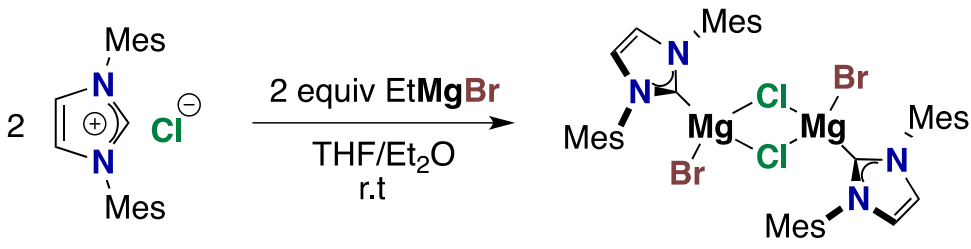

11

Scheme 4. Synthesis of species 11

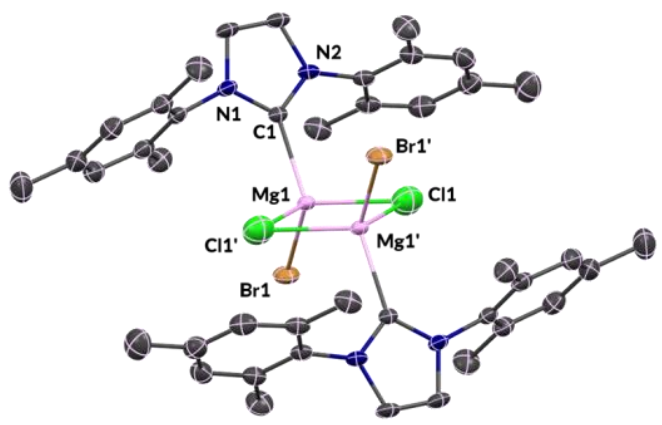

Figure 4. ORTEP representation of $\mathbf{1 1}$ (30\% probability). Hydrogen atoms have been omitted for clarity. Selected bond distances $(\AA)$ and angles $\left(^{\circ}\right)$ : Mg1-C1 2.211(5), Mg1-Cl1 2.372(3), Mg1-Br1 2.432(2), C1-Mg1-C11 108.52(9), C1-Mg1-Br1 113.16(17), C11-Mg1-Cl1 ’ 107.72(13), Cl1-Mg1-Br1 109.39(6).

NHC-supported Mg-alkyl Cations. A primary aim of the present study was to access cationic NHC-supported $\mathrm{Mg}(\mathrm{II})$ alkyls from the set of neutral precursors characterized herein. Ionization of the dimethyl derivative $\left[\mathrm{Mg}(\mathrm{IPr})(\mathrm{Me})_{2}(\mathrm{THF})\right]$ with 1 equiv $\left[\mathrm{Ph}_{3} \mathrm{C}\right]\left[\mathrm{B}\left(\mathrm{C}_{6} \mathrm{~F}_{5}\right)_{4}\right]$ $\left(\mathrm{C}_{6} \mathrm{D}_{5} \mathrm{Br}, \mathrm{RT}\right)$ immediately occurs through a $\mathrm{Me}^{-}$abstraction reaction (formation of $\mathrm{Ph}_{3} \mathrm{CMe}$ evidenced by ${ }^{1} \mathrm{H} \mathrm{NMR}$ ), yet to consistently yield an intractable mixture of compounds in the presence or absence of additional THF. Rather, ionization of methyl halido derivatives 
$[(\mathrm{NHC}) \mathrm{Mg}(\mathrm{Me})(\mathrm{X})]$ through a salt metathesis route allowed access to well-defined $\mathrm{Mg}(\mathrm{II})$ cations. Thus, species 2 and 4 react with 1 equiv. $\mathrm{Na}\left[\mathrm{BPh}_{4}\right](\mathrm{PhF}, \mathrm{RT})$ in the presence of 5 equiv. THF to afford the corresponding cations $\left[\left\{\mathrm{Mg}(\mathrm{IMes})(\mathrm{Me})(\mathrm{THF})_{2}\right]^{+}\right.$(12) and $\left[\left\{\operatorname{Mg}(\operatorname{IPr})(\mathrm{Me})(\mathrm{THF})_{2}\right\}\right]^{+}(\mathbf{1 3})$ as $\mathrm{BPh}_{4}{ }^{-}$salts (Scheme 5), along with a precipitate of $\mathrm{NaBr}$, on the basis of ${ }^{1} \mathrm{H},{ }^{13} \mathrm{C}$ and ${ }^{11} \mathrm{~B}$ NMR data. In particular, ${ }^{1} \mathrm{H}$ NMR data agree with the presence of a $\mathrm{Mg}-$ $\mathrm{Me}^{+}$moiety ( $\delta=-1.62$ and $-1.70 \mathrm{ppm}$ for $\mathbf{1 2}$ and $\mathbf{1 3}$, respectively). The coordination of two THF molecules on $\mathrm{Mg}$ (II) for isolated salts $\mathbf{1 2}$ and $\mathbf{1 3}$ is indicated by significantly upfield shifted ${ }^{1} \mathrm{H}$ NMR resonances for $\mathrm{Mg}-\mathrm{THF}$ (for instance, $\delta=2.88$ and $1.19 \mathrm{ppm}$ for species 12) relative to those of free $\operatorname{THF}(\delta=3.57$ and $1.55 \mathrm{ppm})$. Also, the $\mathrm{C}_{\text {carbene }}$ signals for $\mathbf{1 2}$ and $\mathbf{1 3}(\delta=179.1$ and $181.6 \mathrm{ppm}$, respectively) are upfield shifted compared to those of parent precursors $\mathbf{2}$ and $\mathbf{4}(\delta=$ 186.9 and $186.6 \mathrm{ppm}$ ), which is consistent with a more Lewis acidic $\mathrm{Mg}(\mathrm{II})$ center in cations $\mathbf{1 2}$ and $\mathbf{1 3}$, as expected. ${ }^{16}$ Salts $\mathbf{1 2}$ and $\mathbf{1 3}$, isolated in good yield (over $80 \%$ ) as colorless solids, are stable for weeks in the solid state and days in $\mathrm{PhBr} / \mathrm{PhF}$ at room temperature under inert atmosphere. Both compounds are however unstable in $\mathrm{CH}_{2} \mathrm{Cl}_{2}$ and decompose within minutes at room temperature to unknown species.

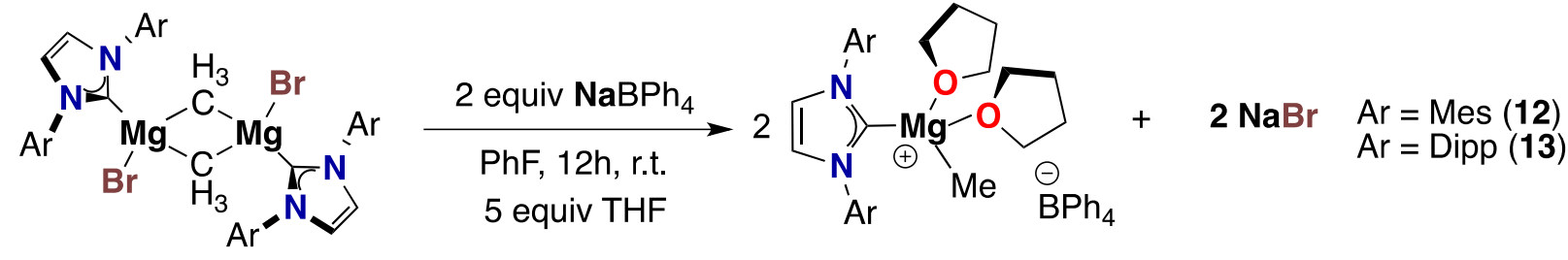

Scheme 5. Synthesis of NHC-Mg(II) alkyl cations 12-13

The molecular structure of species $\mathbf{1 3}$ was confirmed by SC-XRD studies (Figure 5), indicating that its solution structure is retained in the solid state. It thus crystallizes as discrete $\left[\left\{\operatorname{Mg}(\operatorname{IPr})(\mathrm{Me})(\mathrm{THF})_{2}\right\}\right]^{+}$and $\mathrm{BPh}_{4}{ }^{-}$ions with no cation/anion interactions. The mononuclear cation features a central $\mathrm{Mg}$ (II) center lying in a distorted tetrahedral environment, resulting in C(1)$\mathrm{Mg}(1)-\mathrm{C}(28)$ and $\mathrm{O}(1)-\mathrm{Mg}(1)-\mathrm{O}(2)$ angles of 119.65(6) and 94.2(2) ${ }^{\circ}$, respectively. No significant differences were found in the Mg-NHC or Mg-Me bond lengths $(\mathrm{Mg}(1)-\mathrm{C}(1)=2.222(1), \operatorname{Mg}(1)$ $\mathrm{C}(28)=2.133(2) \AA$ ) compared to neutral NHC-supported magnesium adducts. Interestingly, unlike 13, crystallization of mononuclear cation 12 (from $\mathrm{PhF} /$ pentane) affords dinuclear di-cation $\left[\left\{(\mathrm{Mg}(\mathrm{IMes})(\mathrm{THF})\}_{2}(\mu-\mathrm{Me})_{2}\right]^{2+}\left(\mathbf{1 2}\right.\right.$ ', Figure 6) as a $\mathrm{BPh}_{4}^{-}$salt. Thus, despite Coulombic 
repulsions, mono-cation 12 aggregates to form di-cation 12' with concomitant loss of a THF molecule per $\mathrm{Mg}(\mathrm{II})$ center. The formation of 12' clearly reflects both the labile THF coordination to $\operatorname{Mg}(\mathrm{II})$ in solution and the lower steric hindrance of IMes vs. IPr. Cation 12' thus contains two $\mathrm{Mg}$ (II) centers lying in distorted tetrahedral environments with two $\mu$-Me bridging ligands. Unlike neutral dimers discussed herein, the $\mu$-Me groups in 12' disymmetrically bridges the two $\operatorname{Mg}($ II) centers leading to significantly different $\mathrm{Mg}-(\mu$-Me $)$ bond lengths: for instance, $\mathrm{Mg} 1-\mathrm{C} 22=2.205(4)$ and $\mathrm{Mg} 1-\mathrm{C} 22^{\prime}=2.338(4) \AA$. As a comparison, the $\mathrm{Mg}-(\mu-\mathrm{Me})$ bond lengths are nearly identical in neutral dimer $6\left[\left\{(\mathrm{Mg}(\mathrm{IMes})(\mathrm{Cl})\}_{2}(\mu-\mathrm{Me})_{2}\right]\right.$ (Figure 2, Mg1-C22 = 2.313(6), Mg1-C22' = 2.325(6)). The observed bonding parameters in $\mathrm{Mg}-(\mu-\mathrm{Me})-\mathrm{Mg}$ bridges of 12 ' with rather long $\mathrm{Mg} 1-\mathrm{C} 22$ ' and $\mathrm{Mg1}$ '-C22 distances may be sterically and electronically driven: i.e. to limit steric hindrance and Coulombic repulsions.

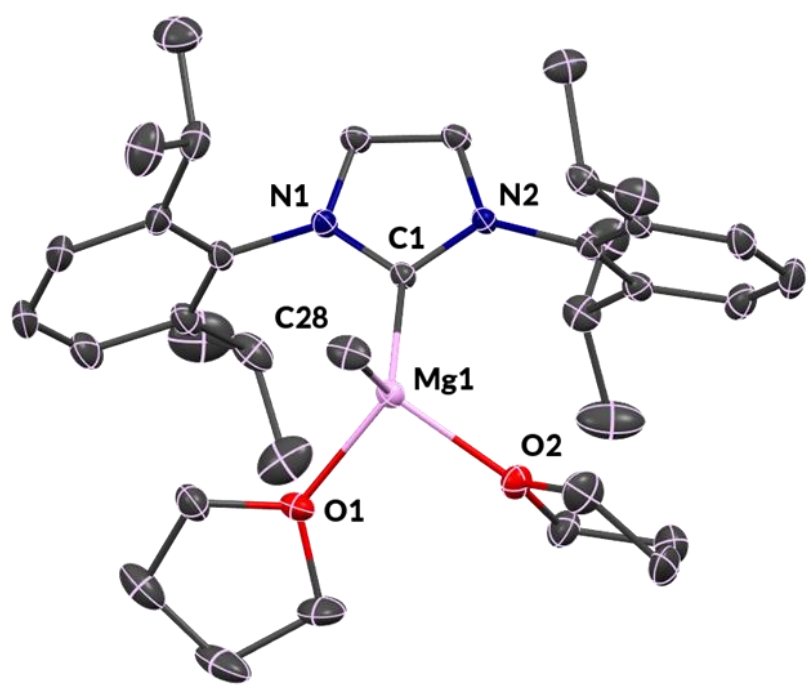

Figure 5. ORTEP representation of $\mathbf{1 3}$ (30\% probability). The anions and hydrogen atoms have been omitted for clarity. Selected bond distances $(\AA)$ and angles $\left(^{\circ}\right)$ : $\mathrm{Mg} 1-\mathrm{C} 12.2224(13)$, Mg1-C28 2.1334(15), Mg1-O1 2.0309(12), Mg1-O2 2.045(7), C1-Mg1-C28 119.65(6), C1-Mg1-O1 111.43(5), C1-Mg1-O2 109.82(18), O1-Mg1-O2 94.19(13). 


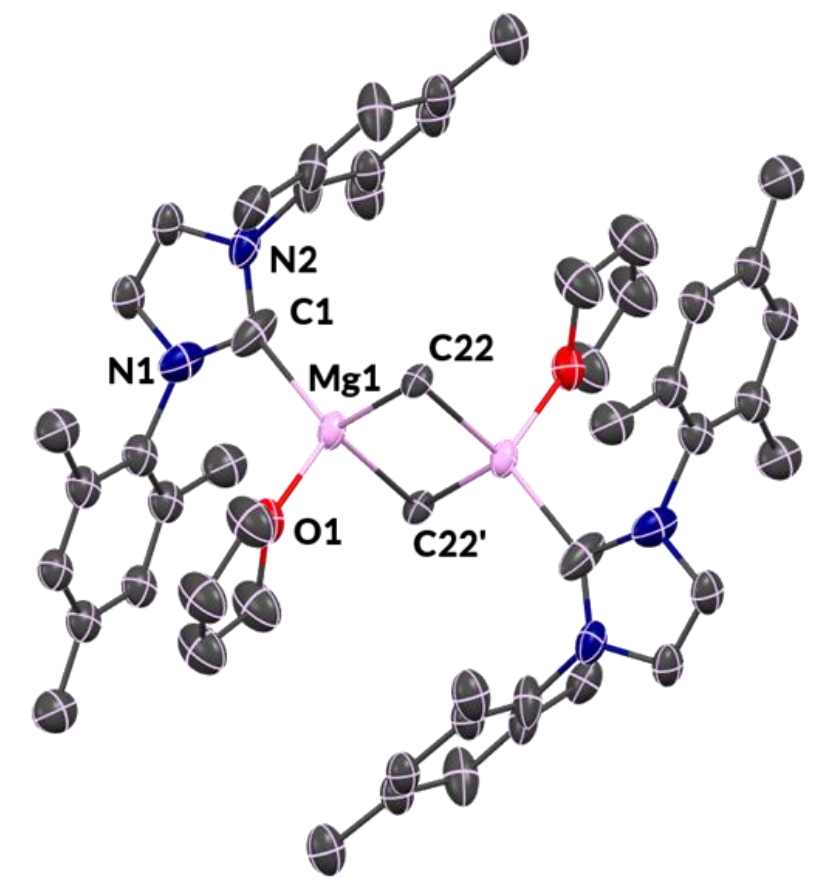

Figure 6: ORTEP representation of 12' (30\% probability). The anions and hydrogen atoms have been omitted for clarity. Selected bond distances $(\AA)$ and angles $\left(^{\circ}\right)$ : Mg1-C1 2.275(6), Mg1-C22 2.205(4), Mg1-C22' 2.338(4), Mg1-O1 2.006(7), C1-Mg1-C22 117.3(2), C1-Mg1-C22' 109.4(2), C1-Mg1-O1 117.6(3), C22-Mg1-O1 100.5(2), C22'-Mg1-O1 104.3(2), C22-Mg1-C22' 106.42(14).

The ionization of dimers $\left[\left\{(\mathrm{Mg}(\mathrm{IMes})(\mathrm{Br})\}_{2}(\mu-\mathrm{Me})_{2}\right](\mathbf{6})\right.$ and $\left[\left\{(\mathrm{Mg}(\operatorname{IPr})(\mathrm{Br})\}_{2}(\mu-\mathrm{Me})_{2}\right](7)\right.$ was also investigated in the absence of any external Lewis base. No reaction was observed between derivative 6 or 7 and 2 equiv $\mathrm{Na}\left[\mathrm{BPh}_{4}\right](\mathrm{PhBr}$ or $\mathrm{PhF}$, room temperature, $24 \mathrm{~h})$ due to the poor solubility of all reagents, leading us to the use of the more soluble salt reagent $\mathrm{Li}\left[\mathrm{B}\left(\mathrm{C}_{6} \mathrm{~F}_{5}\right)_{4}\right]$ as an ionizing agent. An initial monitoring NMR scale reaction of a $1 / 26 / \mathrm{Li}\left[\mathrm{B}\left(\mathrm{C}_{6} \mathrm{~F}_{5}\right)_{4}\right]$ mixture $\left(\mathrm{C}_{6} \mathrm{D}_{5} \mathrm{Br}, 12 \mathrm{~h}\right.$, room temperature) led to the quantitative formation of polynuclear $\mathrm{Mg}(\mathrm{II}) \mathrm{di}$ cation $\left.\left[\{[\mathrm{Mg}(\mathrm{IMes})(\mathrm{Me})][\mathrm{Mg}(\mathrm{IMes})]\}(\mu-\mathrm{Me})_{2}\right]_{2}(\mu-\mathrm{Br})_{2}\right]^{2+}$ as a $\mathrm{B}\left(\mathrm{C}_{6} \mathrm{~F}_{5}\right)_{4}{ }^{-}$salt (14, Scheme 6), along with 1 equiv of unreacted $\mathrm{Li}\left[\mathrm{B}\left(\mathrm{C}_{6} \mathrm{~F}_{5}\right)_{4}\right]$ and formation of a precipitate attributed to $\mathrm{LiBr}$. Heating the reaction mixture $\left(50{ }^{\circ} \mathrm{C}, 2 \mathrm{~h}\right)$ to promote further ionization only led to decomposition products. The generation of cation 14 likely proceeds by a $\mathrm{Br}^{-}$abstraction from dimer $\left[\left\{(\mathrm{Mg}(\mathrm{IMes})(\mathrm{Br})\}_{2}(\mu-\mathrm{Me})_{2}\right]\right.$ to afford transient dinuclear mono-cation $\left[\left\{(\mathrm{Mg}(\mathrm{IMes})\}_{2}(\mu\right.\right.$ $\left.\mathrm{Me})_{2}(\mathrm{Br})\right]^{+}$that then dimerizes to di-cation 14 through formation of two $\mathrm{Mg}-(\mu-\mathrm{Br})-\mathrm{Mg}$ bridges. 
Compound 14 was isolated as colorless crystals in low yield (22 \%) from reaction of a 1/1 6/Li $\left[\mathrm{B}\left(\mathrm{C}_{6} \mathrm{~F}_{5}\right)_{4}\right]$ mixture.
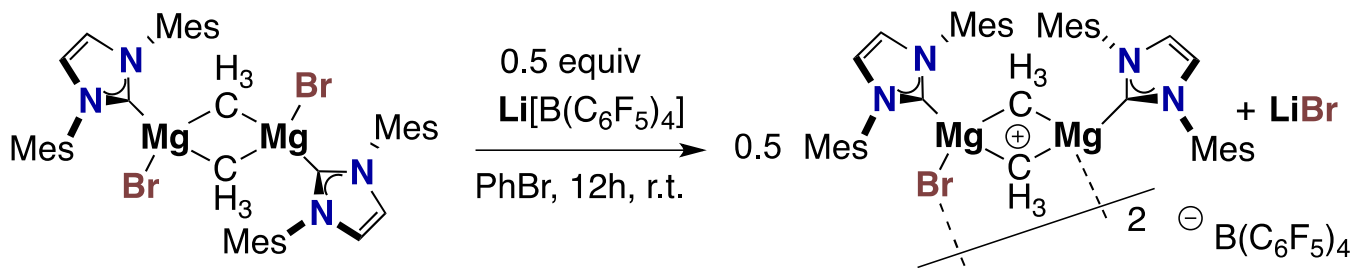

14

Scheme 6. Synthesis of the tetranuclear NHC-Mg(II) cationic complex 14

The molecular structure of 14, as established through SC-XRD analysis, consists of discrete $\left.\left[\{[\mathrm{Mg}(\mathrm{IMes})(\mathrm{Me})][\mathrm{Mg}(\mathrm{IMes})]\}(\mu-\mathrm{Me})_{2}\right]_{2}(\mu-\mathrm{Br})_{2}\right]^{2+}($ Figure 7$)$ and $\mathrm{B}\left(\mathrm{C}_{6} \mathrm{~F}_{5}\right)_{4}{ }^{-}$ions with no cation/anion interactions. The di-cation is comprised of two IMes- $\mathrm{Mg}$ (II) fragments connected by two $\mu$-Me moieties and further assembled by two additional $\mu$ - $\mathrm{Br}$ groups. This results into a $C_{2 \mathrm{v}}$-symmetric central tetranuclear $\left[(\mu-\mathrm{Br}) \mathrm{Mg}(\mu-\mathrm{Me})_{2} \mathrm{Mg}\right]_{2}$ core with each metal center being decorated by a IMes carbene ligand. The $\mathrm{Mg}$ (II) centers are four-coordinate and lie in a slightly distorted tetrahedral environment with, for instance, $\mathrm{C}(1)-\mathrm{Mg}(1)-\mathrm{Br}(1)$ and $\operatorname{Mg}(1)$ $\mathrm{C}(44)-\mathrm{Mg}(1)$ angles of 108.0(2) and 104.7(3) ${ }^{\circ}$, respectively. The $\mathrm{Mg}-\mathrm{NHC}$ bond lengths (2.209(6) and 2.187(6) $\AA$ ) are similar to those of the neutral parent compound 2. The ${ }^{1} \mathrm{H}$ and ${ }^{13} \mathrm{C}$ NMR data for $14\left(\mathrm{C}_{6} \mathrm{D}_{5} \mathrm{Br}\right.$, room temperature $)$ agree with a $C_{2 \mathrm{v}}$-symmetric cationic species, with only one set of NMR resonances for the $\mathrm{Mg}-\mathrm{Me}$ and IMes moieties. The ${ }^{13} \mathrm{C}$ NMR $C_{\text {carbene }}$ signal $(\delta=175.3 \mathrm{ppm})$ is consistent with IMes coordination to $\mathrm{Mg}(\mathrm{II})$. 


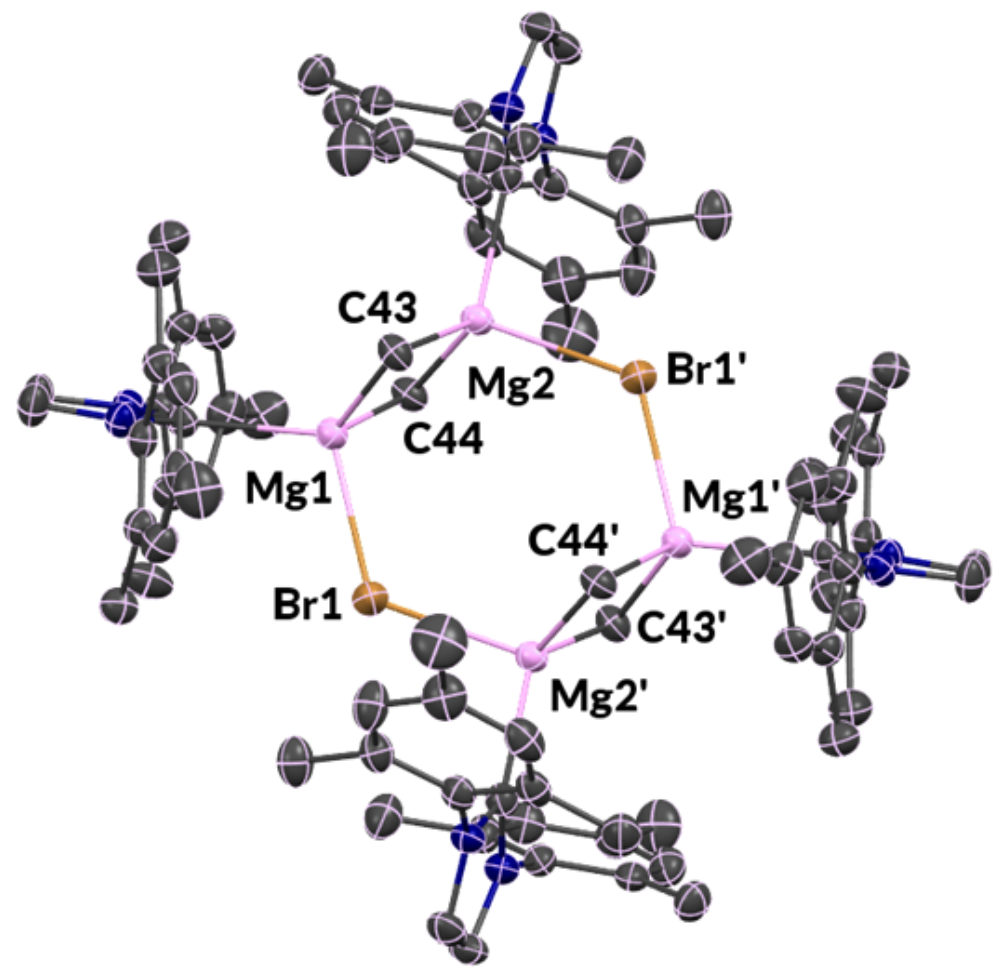

Figure 7. ORTEP representation of $\mathbf{1 4}$ (30\% probability); the anions $\mathrm{B}\left(\mathrm{C}_{6} \mathrm{~F}_{5}\right)_{4}{ }_{4}^{-}$and hydrogen atoms have been omitted for clarity. Selected bond distances $(\AA)$ and angles $\left({ }^{\circ}\right)$ : $\mathrm{Mg} 1-\mathrm{C} 1$ 2.210(6), Mg1-C43 2.234(6), Mg1-C44 2.263(7), Mg1-Br1 2.5204(19), Mg2-C22 2.186(6), Mg2-C43 2.240(7), Mg2-C44 2.231(6), C1-Mg1-Br1 107.97(16), C1-Mg1-C43 113.4(2), C1-Mg1-C44 117.2(3), C43-Mg1-Br1 107.3(2), C44-Mg1-Br1 105.72(17), C22-Mg2-C43 118.2(2), C22-Mg2-C44 114.5(2), C43-Mg1-C44 104.6(2), C43-Mg2-C44 105.5(2).

In preliminary reactivity studies, cationic $\mathrm{Mg}-\mathrm{NHC}$ alkyls $\mathbf{1 2}$ and $\mathbf{1 3}$ were observed to react fast and quantitatively with 1 equiv. of $\mathrm{PhSiH}_{3}$ (THF- $d^{8}$ or $\mathrm{C}_{6} \mathrm{D}_{5} \mathrm{Br}, 5 \mathrm{~min}$, room temperature) through presumably an alkyl-hydride exchange reaction (as deduced from the quantitative formation of $\mathrm{PhEtSiH}_{2}$ ), a reactivity well-established for neutral $\mathrm{Mg}$-alkyl species. ${ }^{17}$ Yet, the putatively formed $\mathrm{Mg}-\mathrm{H}$ species are instable under the studied conditions to decompose to insoluble and unidentified material. ${ }^{18}$

DFT-estimated electronic structure of NHC-supported $\mathbf{M g}(\mathrm{II})$ species. The electronic structure and bonding features of selected neutral and cationic Mg-NHC species prepared herein were DFT-computed. First, as estimated at the PBEPBE/6-31+G** theory level, ${ }^{19,20}$ the bonding 
and geometrical parameters at the $\operatorname{Mg}(\mathrm{II})$ centers for model compounds ${ }^{21}\left[\left\{(\operatorname{Mg}(\operatorname{IPr})(\mathrm{Me})\}_{2}(\mu\right.\right.$ $\left.\mathrm{Me})_{2}\right] \quad\left(\mathbf{V}^{\prime}\right), \quad\left[\left\{(\mathrm{Mg}(\mathrm{IMes})(\mathrm{Br})\}_{2}(\mu-\mathrm{Me})_{2}\right] \quad(\mathbf{V I}), \quad\left[\left\{(\mathrm{Mg}(\mathrm{IPr})(\mathrm{Br})\}_{2}(\mu-\mathrm{Me})_{2}\right] \quad(\mathbf{V I I})\right.\right.$, $\left[\left\{(\mathrm{Mg}(\mathrm{IMes})(\mathrm{THF})\}_{2}(\mu-\mathrm{Me})_{2}\right]^{2+}(\mathbf{X I I}),\left[\left\{\operatorname{Mg}(\mathrm{IPr})(\mathrm{Me})(\mathrm{THF})_{2}\right\}\right]^{+}\right.$(XIII) agree well with SCXRD-characterized species 5', 6, 7 and 12' and 13 (Table S1, Supporting Information). For all species, $\mathrm{NBO}$ analysis of the bonding at $\mathrm{Mg}$ (II) are consistent with essentially ionic $\mathrm{Mg}$-alkyl and $\mathrm{Mg}-\mathrm{NHC}$ bonds with Wiberg indexes (WI) ranging from 0.22 for the $\mathrm{Mg}-(\mu-\mathrm{Me})$ bonds in V' to 0.35 for the $\mathrm{Mg}-\mathrm{Me}$ bond in di-cation XII' (Table S2, Supporting Information). The bonding of terminal ligands to $\mathrm{Mg}(\mathrm{II})$ is a bit more covalent as reflected by WI values of 0.38 , 0.53 and 0.56 for, respectively, the $\mathrm{Mg}-\mathrm{Me}$ bond in $\mathbf{V}$ and the $\mathrm{Mg}-\mathrm{Br}$ bonds in $\mathrm{VI}$ and VII. The positive charge at $\mathrm{Mg}$ (II) ranges from 1.12 to 1.25 for neutral models and is of 1.35 and 1.40 for cations XII' and XIII, respectively, in line with a more electro-deficient $\mathrm{Mg}(\mathrm{II})$ center upon cationization. The overall electrostatic bonding of the model $\operatorname{Mg}$ (II) complexes was further supported by the electron localization function (ELF) topological analysis (Table S3, Supporting Information). As deduced from ELF isosurfaces computed for model $\mathbf{V}$ ' (Figure 8), no valence basins was identified between the $\mathrm{Mg}$ (II) center and the supporting ligands (bridging or terminal $\mathrm{Me}^{-}$and $\mathrm{IPr}$ ). A minor covalent character is present in the $\mathrm{Mg}-\mathrm{Br}$ bonds as shown by the presence of a $\mathrm{Mg}-\mathrm{Br}$ valence basin. However, these basins can be considered as ligand lone pair with a neglectable electronic contribution of the $\mathrm{Mg}(\mathrm{II})$ cation to these basins (Table S3).
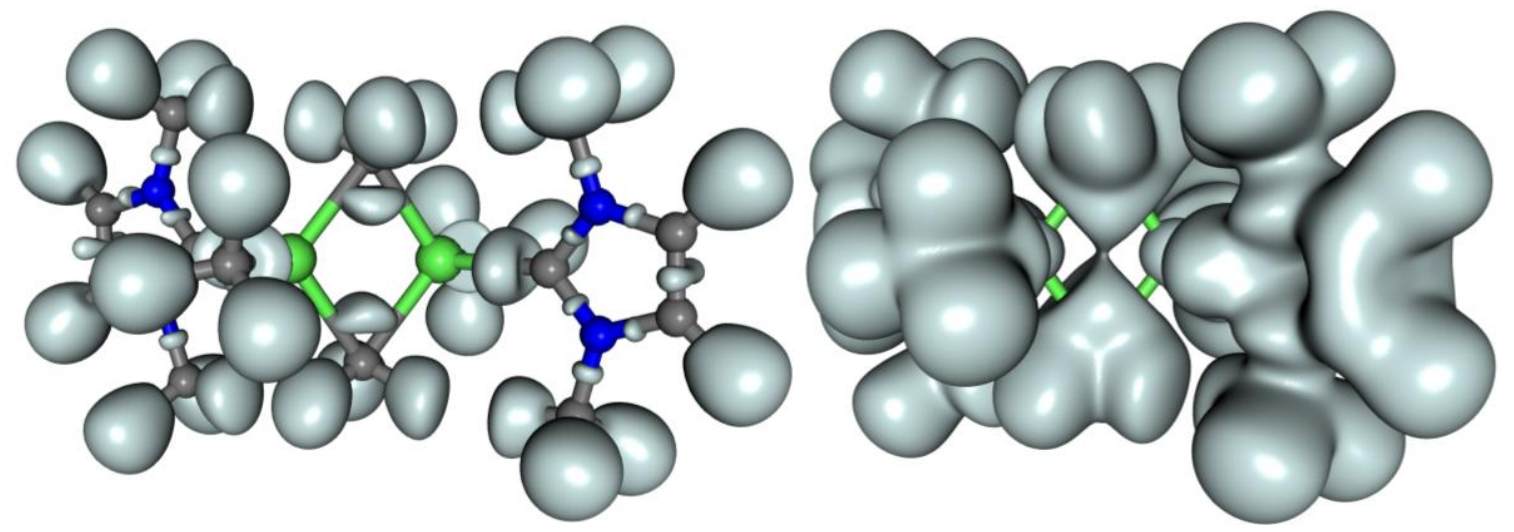

Figure 8. Electron Localization Funtion (ELF) isosurface (left, $\eta=8.87$; right, $\eta=0.27$ ) for a simplified model of $\mathbf{V}$ (the $N$-Dipp are replaced by $N$-Me groups for shorter calculation time).

Non Covalent Interactions (NCI) analyses were also computed and further support the predominance of attractive electrostatic forces for $\mathrm{Mg}$ (II)-ligand interactions, as illustrated in the 
case of model $\mathbf{V}^{\prime}$ (Figure 9). Interestingly, the NCI and ELF data for $\mathbf{V}^{\prime}$ also provide a rationale to the rather short $\mathrm{Mg} \cdots \mathrm{Mg}$ distances observed for all structurally characterized $\mathrm{NHC}-\mathrm{Mg}$ dimers. Thus, as shown in Figure 9, the NCI for $\mathbf{V}$ ' feature repulsive and attractive forces between the $\mathrm{Mg}(\mathrm{II})$ centers, while only Coulombic repulsion would be expected between cations. Yet, from the ELF plot (Figure 8), the lone pair basins of the bridging Me groups connect at low isosurface value suggesting the presence of electron density between the $\mathrm{Mg}$ (II) centers. Such density arising from the two $\mu$-Me groups results in Coulombic attraction with both $\mathrm{Mg}(\mathrm{II})$ centers, hence a shorter $\mathrm{Mg}-\mathrm{Mg}$ distance than expected.

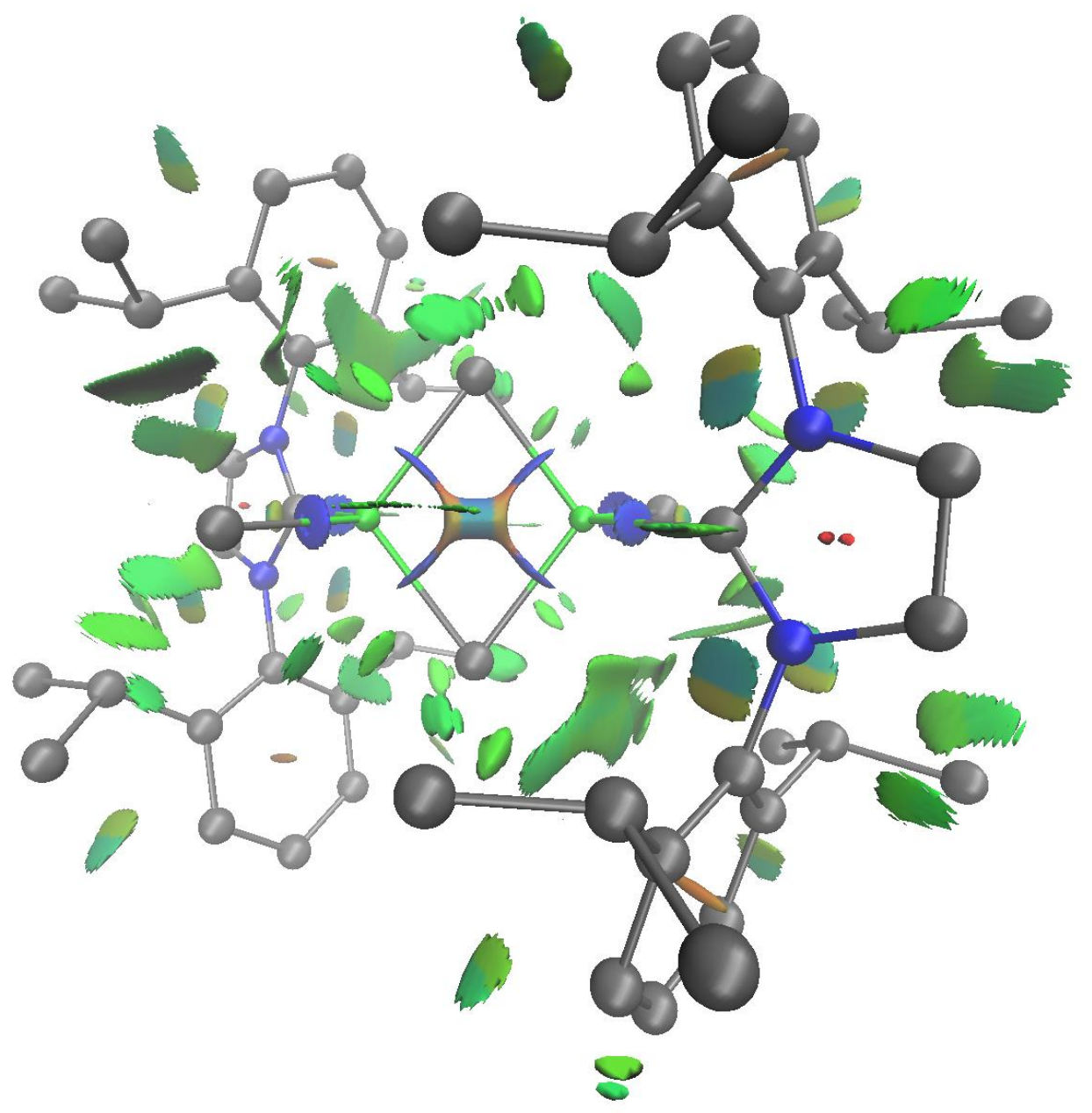

Figure 9. Non Covalent Interactions (NCI) analysis for model species $\mathbf{V}^{\prime}$. Hydrogen atoms are omitted for clarity. The green basins represent area where attractive dispersive forces are present. The blue basins show the presence of attractive electrostatic forces. In red are displayed areas of steric clashes. 


\section{Conclusion}

A series of neutral complexes NHC-supported Grignard reagents and dialkyl $\mathrm{Mg}$ (II) species were synthesized and thoroughly structurally characterized, further establishing their strong tendency towards aggregation with the formation of $[(\mathrm{NHC}) \mathrm{Mg}(\mathrm{R})(\mathrm{X})]_{2}$ dimeric adducts. Though mononuclear $\mathrm{Mg}-\mathrm{THF}$ adducts [(NHC) $\mathrm{Mg}(\mathrm{R})(\mathrm{X})(\mathrm{THF})]$ may be isolated, all data suggest that THF coordination to $\mathrm{Mg}$ (II) is labile as reflected by the characterization of dimeric adduct 5' from mononuclear THF adduct 5. These Grignard NHC adducts were successfully ionize to cationic NHC magnesium alkyls through halide abstraction. Akin to their neutral parent precursors, the structure of the resulting cations is strongly dependent upon reaction medium. The presence of THF allowed access to mononuclear NHC-supported Mg-alkyl cations 12 and 13. The labile nature of the Mg-THF interaction in such cations was also clearly evidenced with the formation of dimeric di-cation 12' arising from aggregation of bis-THF mono-cation 12. Accordingly, carrying the ionization $[(\mathrm{NHC}) \mathrm{Mg}(\mathrm{R})(\mathrm{X})]$-type species in the absence of THF may lead to larger cationic aggregates, as illustrated by the formation of tetranuclear $\mathrm{NHC}-\mathrm{Mg}(\mathrm{II}) \mathrm{di}-$ cation 14. As computed for selected neutral and cationic derivatives, the bonding at $\operatorname{Mg}(\mathrm{II})$ is essentially dominated by electrostatic interactions, which also rationalizes the rather short $\mathrm{Mg}{ }^{\cdots} \mathrm{Mg}$ distances systematically observed in all structurally characterized $\mathrm{Mg}$ (II) dimers.

\section{Experimental Section}

\section{General considerations}

All experiments were carried out under $\mathrm{N}_{2}$ using standard Schlenk techniques or in a MBraun Labmaster 130 glovebox. Toluene and pentane were collected after going through drying columns (MB SPS-800), then distilled under $\mathrm{N}_{2}$ (over $\mathrm{Na} /$ benzophenone, or $\mathrm{CaH}_{2}$ ), and stored at last over molecular sieves ( $4 \AA$ ) for $24 \mathrm{~h}$ in a glovebox prior to use. All deuterated solvents were purchased from Sigma-Aldrich, excepted for $\mathrm{C}_{6} \mathrm{D}_{5} \mathrm{Br}$, purchased from ABCR GmbH \& Co. They were stored over molecular sieves ( $4 \AA$ ) for $24 \mathrm{~h}$ prior to use. Anhydrous $\mathrm{MgBr}_{2}$ was purchased from Strem Chemicals and used as received. Methyllithium 1.6 $\mathrm{M}$ in $\mathrm{Et}_{2} \mathrm{O}$, Grignard Reagent 
Solutions (EtMgBr, $\mathrm{BnMgCl}$ at $1.0 \mathrm{M}$ and $\mathrm{MeMgBr}, \mathrm{PhMgBr}$ at $3.0 \mathrm{M}$, in $\mathrm{Et}_{2} \mathrm{O}$ ) were all purchased from Sigma-Aldrich and used as received. IMesHCl, IPrHCl, IMes, and IPr were prepared according to literature procedures. ${ }^{22}$ All NMR measurements were performed with Teflon-valve J. Young NMR tubes at ambient conditions. Proton $\left({ }^{1} \mathrm{H}\right.$ NMR $)$ and carbon $\left({ }^{13} \mathrm{C}\left\{{ }^{1} \mathrm{H}\right\}\right.$ NMR) nuclear magnetic resonance spectra were recorded on the following instrument: Bruker AVANCE I - $500 \mathrm{MHz}$ spectrometer. The chemical shifts are given in part per million (ppm). Chemical shifts are given in ppm, ${ }^{1} \mathrm{H}$ and ${ }^{13} \mathrm{C}$ shifts are reported towards $\mathrm{SiMe}_{4}$, and were determined relative to the residual signals of deuterated solvents as internal references, while ${ }^{19} \mathrm{~F}$ and ${ }^{11} \mathrm{~B}$ NMR shifts are reported respectively towards $\mathrm{BF}_{3}$ and $\mathrm{H}_{3} \mathrm{BO}_{3}$ as external references. Data are presented as follows: chemical shift, multiplicity $(\mathrm{s}=$ singlet, $\mathrm{d}=$ doublet, $\mathrm{t}=$ triplet, $\mathrm{q}=$ quartet, sept $=$ septuplet, $\mathrm{m}=$ multiplet, $\mathrm{br}=$ broad $)$, coupling constants $(\mathrm{J} / \mathrm{Hz})$ and integration. For the X-ray diffraction studies, the intensity data were collected at 173(2) K on a Bruker KAPPA APEX II DUO diffractometer or on a Bruker KappaCCD diffractometer (compound 8). Crystallographic and experimental details for all the structures are summarized in the Supporting Information (page S17). The structures were solved by direct methods (SIR-97 or SHELXS-2013 or SHELXS-2014) and refined by full-matrix least-squares procedures (based on $F^{2}$, SHELXL2013 or SHELXL-2014) with anisotropic thermal parameters for all the non-hydrogen atoms. ${ }^{23,24}$ The hydrogen atoms were introduced into geometrically calculated positions (SHELXL-2013 or SHELXL-2014 procedures) and refined riding on the corresponding parent atoms. Despite numerous attempts and akin to previous reports, satisfactory elemental analyses could not be collected for the NHC magnesium complexes due to their very sensitive nature. ${ }^{8 \mathrm{~h}, 8 \mathrm{i}}$

Preparation of $[\mathrm{Mg}(\mathrm{IMes})(\mathbf{E t})(\mathrm{Br})(\mathrm{THF})](1)$. In a glovebox, 1.05 equiv. of ethylmagnesium bromide in $\mathrm{Et}_{2} \mathrm{O}$ solution $(1.00 \mathrm{ml}, 0.99 \mathrm{mmol})$ was added dropwise to a cold solution of THF ($\left.35{ }^{\circ} \mathrm{C}\right)$ containing 1 equiv. of free IMes $(0.287 \mathrm{~g}, 0.94 \mathrm{mmol})$. The mixture was stirred for 4 hours at room temperature. Then, THF was removed under reduced pressure, and the resulting white powder was washed with $10 \mathrm{ml}$ of pentane to afford complex $1(0.451 \mathrm{~g}, 96 \%)$. ${ }^{1} \mathrm{H} \mathrm{NMR}$ (500 MHz, $d_{8}$-THF): -1.18 (q, $\left.{ }^{3} J=7.7 \mathrm{~Hz}, 2 \mathrm{H}, \mathrm{MgEt}\right), 0.82\left(\mathrm{t},{ }^{3} \mathrm{~J}=7.7 \mathrm{~Hz}, 3 \mathrm{H}, \mathrm{MgEt}\right), 1.77$ (m, 4H, THF), 2.15 (s, 12H, $\operatorname{Ar}(o-\mathrm{Me})$ ), 2.33 (s, 6H, $\operatorname{Ar}(p-\mathrm{Me})$ ), 3.62 (m, 4H, THF), 7.02 (s, 4H, $\operatorname{Ar}(m-\mathrm{H})), 7.27$ (s, 2H, Im(H)); ${ }^{13} \mathrm{C}$ NMR (125 MHz, $\left.d_{8}-\mathrm{THF}\right):-1.1(\mathrm{MgEt}), 13.4(\mathrm{MgEt}), 18.0$ (Ar(o-Me)), 20.9 (Ar(p-Me)), 26.2 (THF), 68.0 (THF), $123.4(\operatorname{Im}(\mathrm{CH})), 129.6$ (Ar(CH)), 136.3 (Ar), $137.0(\mathrm{Ar}), 139.3\left(\operatorname{Ar}\left(\mathrm{C}_{i p s o}\right)\right), 187.2$ (carbene). 
Preparation of $[\mathrm{Mg}(\mathrm{IMes})(\mathrm{Me})(\mathrm{Br})(\mathrm{THF})]$ (2). Following a protocol used for 2, 1.05 equiv. of methylmagnesium bromide in $\mathrm{Et}_{2} \mathrm{O}$ solution $(0.7 \mathrm{ml}, 2.10 \mathrm{mmol})$ and 1 equiv. of free IMes $(0.506$ $\mathrm{g}, 1.99 \mathrm{mmol})$ produced complex 3 as an off-white powder $(0.953 \mathrm{~g}, 96 \%)$. ${ }^{1} \mathrm{H}$ NMR $(500 \mathrm{MHz}$, $d_{8}$-THF): -2.03 (s, 3H, MgMe), 1.77 (m, 4H, THF), 2.15 (s, 12H, Ar(o-Me)), 2.33 (s, 6H, Ar(p$\mathrm{Me})$ ), 3.62 (m, 4H, THF), $7.01(\mathrm{~s}, 4 \mathrm{H}, \operatorname{Ar}(m-\mathrm{H})), 7.27$ (s, 2H, Im(H)); ${ }^{13} \mathrm{C}$ NMR $\left(125 \mathrm{MHz}, d_{8^{-}}\right.$ THF): -15.4 (MgMe), 18.0 (Ar(o-Me)), 20.9 (Ar(p-Me)), 26.2 (THF), 68.0 (THF), 123.4 $(\operatorname{Im}(\mathrm{CH})), 129.5(\mathrm{Ar}(\mathrm{CH})), 136.3(\mathrm{Ar}), 136.7(\mathrm{Ar}), 139.3\left(\mathrm{Ar}\left(\mathrm{C}_{\text {ipso }}\right)\right), 186.9$ (carbene).

Preparation of $[\mathrm{Mg}(\mathrm{IPr})(\mathrm{Et})(\mathrm{Br})(\mathrm{THF})]$ (3). Following a protocol used for 2, 1.06 equiv. of ethylmagnesium bromide in $\mathrm{Et}_{2} \mathrm{O}$ solution $(0.9 \mathrm{ml}, 0.92 \mathrm{mmol})$ and 1 equiv. of free $\operatorname{IPr}(0.340 \mathrm{~g}$, $0.87 \mathrm{mmol})$ produced complex 3 as an off-white powder $(0.411 \mathrm{~g}, 95 \%) .{ }^{1} \mathrm{H}$ NMR $(500 \mathrm{MHz}$, $d_{8}$-THF): -1.18 (m, 2H, MgEt), 0.85 (m, 3H, MgEt), 1.15 (d, ${ }^{3} J=6.7 \mathrm{~Hz}, 12 \mathrm{H}, \mathrm{CH}_{3}-\mathrm{Pr}$ ), 1.29 (d, $\left.{ }^{3} J=6.7 \mathrm{~Hz}, 12 \mathrm{H}, \mathrm{CH}_{3}-i \mathrm{Pr}\right), 1.77$ (m, 4H, THF), 2.84 (sp, $\left.{ }^{3} J=6.7 \mathrm{~Hz}, 4 \mathrm{H}, \mathrm{CH}-i \mathrm{Pr}\right), 3.62$ (m, 4H, THF), 7.31 (d, $\left.{ }^{3} J=7.7 \mathrm{~Hz}, 4 \mathrm{H}, \operatorname{Ar}(m-\mathrm{H})\right), 7.34(\mathrm{~s}, 2 \mathrm{H}, \operatorname{Im}(\mathrm{H})), 7.42\left(\mathrm{t},{ }^{3} J=7.7 \mathrm{~Hz}, 2 \mathrm{H}, \operatorname{Ar}(p-\mathrm{H})\right)$; ${ }^{13} \mathrm{C}$ NMR (125 MHz, $d_{8}$-THF): -1.2 (MgEt), 13.5 (MgEt), $23.9\left(\mathrm{CH}_{3}-i \mathrm{Pr}\right), 25.6\left(\mathrm{CH}_{3}-i \mathrm{Pr}\right), 26.1$ (THF), 29.1 (CH-iPr), 68.0 (THF), 124.2 (Im(CH)), $124.4(\operatorname{Ar}(\mathrm{CH})) 130.0(\mathrm{Ar}(\mathrm{CH})), 137.6(\mathrm{Ar})$, $146.7\left(\operatorname{Ar}\left(\mathrm{C}_{i p s o}\right)\right)$.

Preparation of $[\mathrm{Mg}(\mathrm{IPr})(\mathrm{Me})(\mathrm{Br})(\mathrm{THF})](4)$. Following a protocol used for 2, 1.05 equiv. of methylmagnesium bromide in $\mathrm{Et}_{2} \mathrm{O}$ solution $(0.5 \mathrm{ml}, 1.57 \mathrm{mmol})$ and 1 equiv. of free $\operatorname{IPr}(0.582$ g, $1.50 \mathrm{mmol})$ produced complex 4 as a white powder $(0.717 \mathrm{~g}, 97 \%)$. ${ }^{1} \mathrm{H}$ NMR $\left(500 \mathrm{MHz}, \mathrm{d}_{8^{-}}\right.$ THF): -2.03 (s, 3H, MgMe), 1.15 (d, $\left.{ }^{3} J=6.6 \mathrm{~Hz}, 12 \mathrm{H}, \mathrm{CH}_{3}-\mathrm{Pr}\right), 1.28\left(\mathrm{~d},{ }^{3} J=6.6 \mathrm{~Hz}, 12 \mathrm{H}, \mathrm{CH}_{3^{-}}\right.$ $i \mathrm{Pr}$ ), 1.77 (m, 4H, THF), 2.84 (sp, $\left.{ }^{3} J=6.6 \mathrm{~Hz}, 4 \mathrm{H}, \mathrm{CH}-i \mathrm{Pr}\right), 3.62$ (m, 4H, THF), 7.29 (d, ${ }^{3} J=7.7$ $\mathrm{Hz}, 4 \mathrm{H}, \operatorname{Ar}(m-\mathrm{H})), 7.34(\mathrm{~s}, 2 \mathrm{H}, \operatorname{Im}(\mathrm{H})), 7.41\left(\mathrm{t},{ }^{3} \mathrm{~J}=7.7 \mathrm{~Hz}, 2 \mathrm{H}, \operatorname{Ar}(p-\mathrm{H})\right) ;{ }^{13} \mathrm{C}$ NMR $(125 \mathrm{MHz}$, $\mathrm{d}_{8}$-THF): -17.6 (MgMe), 22.4 ( $\mathrm{CH}_{3}$-iPr), 22.6 ( $\mathrm{CH}_{3}$-iPr), 23.5 (THF), 26.5 (CH-iPr), 64.9 (THF), 121.6 (Im(CH)), $121.6(\operatorname{Ar}(\mathrm{CH})) 127.4(\mathrm{Ar}(\mathrm{CH})), 134.9(\mathrm{Ar}), 146.0\left(\mathrm{Ar}\left(\mathrm{C}_{\text {ipso }}\right)\right), 186.6$ (carbene).

Preparation of $\left[\mathrm{Mg}(\mathrm{IPr})(\mathrm{Me})_{2}(\mathrm{THF})\right](5)$. In a glovebox, 1 equiv. of methyllithium in hexane solution $(80 \mu \mathrm{L}, 0.12 \mathrm{mmol})$ was slowly added to a cold solution $\left(-35^{\circ} \mathrm{C}\right)$ of 1 equiv. of $[\mathrm{Mg}(\mathrm{IPr})(\mathrm{Me})(\mathrm{Br})(\mathrm{THF})](5)(0.045 \mathrm{~g}, 0.12 \mathrm{mmol})$ solubilized in $1 \mathrm{ml}$ of THF. The formation of a precipitate was observed after $15 \mathrm{~min}$ while the solution had turned orange. After filtration over a plug of kieselguhr, the solution was dried out. The residues were washed with pentane to afford 6 as a white powder $(0.037 \mathrm{~g}, 75 \%)$. ${ }^{1} \mathrm{H}$ NMR (500 MHz, $d_{8}$-THF): -1.93 (s, 6H, $\mathrm{MgMe}_{2}$ ), 1.16 
$\left(\mathrm{d},{ }^{3} J=6.8 \mathrm{~Hz}, 12 \mathrm{H}, \mathrm{CH}_{3}-i \mathrm{Pr}\right), 1.22\left(\mathrm{~d},{ }^{3} J=6.8 \mathrm{~Hz}, 12 \mathrm{H}, \mathrm{CH}_{3}-i \mathrm{Pr}\right), 1.77$ (m, 4H, THF), 2.82 (sp, $\left.{ }^{3} J=6.7 \mathrm{~Hz}, 4 \mathrm{H}, \mathrm{CH}-i \mathrm{Pr}\right), 3.62(\mathrm{~m}, 4 \mathrm{H}, \mathrm{THF}), 7.25$ (s, 2H, Im(H)), 7.27 (d, ${ }^{3} J=7.8 \mathrm{~Hz}, 4 \mathrm{H}$, $\operatorname{Ar}(m-\mathrm{H})), 7.38\left(\mathrm{t},{ }^{3} J=7.8 \mathrm{~Hz}, 2 \mathrm{H}, \operatorname{Ar}(p-\mathrm{H})\right) ;{ }^{13} \mathrm{C}$ NMR $\left(125 \mathrm{MHz}, d_{8}-\mathrm{THF}\right):-15.9\left(\mathrm{MgMe}_{2}\right)$, $24.1\left(\mathrm{CH}_{3}-i \mathrm{Pr}\right), 24.4\left(\mathrm{CH}_{3}-i \mathrm{Pr}\right), 26.1$ (THF), 29.0 (CH-iPr), 68.0 (THF), $123.3(\mathrm{Ar}(\mathrm{CH})), 123.9$ $(\operatorname{Im}(\mathrm{CH})), 129.5(\operatorname{Ar}(\mathrm{CH})), 138.4(\mathrm{Ar}), 146.6\left(\operatorname{Ar}\left(\mathrm{C}_{i p s o}\right)\right)$.

Preparation of $\left[\left\{(\mathrm{Mg}(\mathrm{IMes})(\mathrm{Br})\}_{2}(\mu \text {-Me })_{2}\right](6)\right.$. Procedure 1: In a glovebox, 1.05 equiv. of methylmagnesium bromide in $\mathrm{Et}_{2} \mathrm{O}$ solution $(0.4 \mathrm{ml}, 1.10 \mathrm{mmol})$ was added dropwise to 1 equiv. of free IMes $(0.318 \mathrm{~g}, 1.04 \mathrm{mmol})$ dissolved in $5 \mathrm{ml}$ of toluene and $5 \mathrm{ml}$ of diethyl ether (1:1) at $35{ }^{\circ} \mathrm{C}$. After 4 hours at room temperature, a precipitate was formed and the solvents were removed under reduced pressure. Two triturations/filtrations made with $10 \mathrm{ml}$ of solutions containing 1:5 volumes of toluene:pentane, followed by one trituration/filtration made with $5 \mathrm{ml}$ of pentane produced 6 as a white powder $(0.376 \mathrm{~g}, 85 \%)$. ${ }^{1} \mathrm{H}$ NMR $\left(500 \mathrm{MHz}, \mathrm{C}_{6} \mathrm{D}_{5} \mathrm{Br}\right):-1.96$ (s, 3H, MgMe), 2.00 (s, 12H, $\operatorname{Ar}(o-\mathrm{Me})$ ), 2.22 (s, 6H, $\operatorname{Ar}(p-\mathrm{Me})$ ), 6.44 (s, 2H, Im(CH)), 6.64 (s, 4H, $\operatorname{Ar}(m-\mathrm{H})) ;{ }^{13} \mathrm{C}\left\{{ }^{1} \mathrm{H}\right\}$ NMR $\left(125 \mathrm{MHz}, \mathrm{C}_{6} \mathrm{D}_{5} \mathrm{Br}\right):-14.9(\mathrm{MgMe}), 17.6(\operatorname{Ar}(o-\mathrm{Me})), 21.0(\operatorname{Ar}(p-\mathrm{Me}))$, $118.0(\operatorname{Im}(\mathrm{CH})), 134.6(\mathrm{Ar}), 135.0(\mathrm{Ar}), 138.4(\mathrm{Ar}), 182.0$ (carbene).

Procedure 2: In a glovebox, 1 equiv. of anhydrous magnesium bromide $(0.193 \mathrm{~g}, 1.05 \mathrm{mmol})$ was added to $12 \mathrm{~mL}$ of diethyl ether containing 1 equiv. of free IMes $(0.320 \mathrm{~g}, 1.05 \mathrm{mmol})$. The solution was stirred until dissolution of $\mathrm{MgBr}_{2}$ and cooled down to $-35^{\circ} \mathrm{C}$. Then 1.05 equiv. of methyllithium in $\mathrm{Et}_{2} \mathrm{O}$ solution $(0.4 \mathrm{ml}, 1.10 \mathrm{mmol})$ was added dropwise. After 1 hour at room temperature, a precipitate attributed to the formation of $\mathrm{LiBr}$ was discarded upon filtration through a glass frit (porosity 5) and the solvent was removed under pressure. The residues were twice triturated/filtered with $10 \mathrm{ml}$ of a solution containing 1:5 volumes of toluene:pentane, and once with $5 \mathrm{ml}$ of pentane yielding 7 as a white powder $(0.141 \mathrm{~g}, 32 \%)$.

Preparation of $\left[(\operatorname{Mg}(\operatorname{IPr})(\mathrm{Br})(\mu-\mathrm{Me})]_{2}\right.$ (7). Following the protocol 1 used for 6, 1 equiv. of methylmagnesium bromide in $\mathrm{Et}_{2} \mathrm{O}$ solution $(0.3 \mathrm{ml}, 0.87 \mathrm{mmol})$ and 1 equiv. of free $\operatorname{IPr}(0.320$ g, $0.87 \mathrm{mmol})$ produced 7 as a white powder $(0.340 \mathrm{~g}, 81 \%) .{ }^{1} \mathrm{H}$ NMR $\left(500 \mathrm{MHz}, \mathrm{C}_{6} \mathrm{D}_{5} \mathrm{Br}\right)$ : 2.07 (s, 3H, MgMe), 0.94 (d, $\left.{ }^{3} J=6.6 \mathrm{~Hz}, 12 \mathrm{H}, \mathrm{CH}_{3}-i \mathrm{Pr}\right), 1.37\left(\mathrm{~d},{ }^{3} J=6.6 \mathrm{~Hz}, 12 \mathrm{H}, \mathrm{CH}_{3}-i \mathrm{Pr}\right.$ ), $2.80\left(\mathrm{sp},{ }^{3} J=6.6 \mathrm{~Hz}, 4 \mathrm{H}, \mathrm{CH}-i \mathrm{Pr}\right), 6.82(\mathrm{~s}, 2 \mathrm{H}, \operatorname{Im}(\mathrm{CH})), 7.03\left(\mathrm{~d},{ }^{3} J=7.6 \mathrm{~Hz}, 4 \mathrm{H}, \operatorname{Ar}(m-\mathrm{H})\right.$ ), $7.22\left(\mathrm{t},{ }^{3} J=7.6 \mathrm{~Hz}, 2 \mathrm{H}, \operatorname{Ar}(p-\mathrm{H})\right) ;{ }^{13} \mathrm{C}\left\{{ }^{1} \mathrm{H}\right\}$ NMR (125 MHz, $\left.\mathrm{C}_{6} \mathrm{D}_{5} \mathrm{Br}\right):-14.2(\mathrm{MgMe}), 23.3$ 
$\left(\mathrm{CH}_{3}-i \mathrm{Pr}\right), 25.6\left(\mathrm{CH}_{3}-i \mathrm{Pr}\right), 28.1(\mathrm{CH}-i \mathrm{Pr}), 123.7(\mathrm{Im}(\mathrm{CH})), 130.1$ (Ar), 134.7 (Ar), 145.5 (Ar), 185.0 (carbene).

Preparation of $\left[\left\{(\mathbf{M g}(\mathrm{IMes})(\mathbf{P h})\}_{2}(\mu-\mathrm{Br})_{2}\right](\mathbf{8})\right.$. Following the protocol 1 used for 7, 1.06 equiv. of phenylmagnesium bromide in $\mathrm{Et}_{2} \mathrm{O}$ solution $(0.3 \mathrm{ml}, 0.95 \mathrm{mmol})$ and 1 equiv. of free IMes $(0.275 \mathrm{~g}, 0.90 \mathrm{mmol})$ produced 8 as a white powder $(0.424 \mathrm{~g}, 78 \%) .{ }^{1} \mathrm{H}$ NMR $(500 \mathrm{MHz}$, $\left.\mathrm{C}_{6} \mathrm{D}_{5} \mathrm{Br}\right): 1.83$ (s, 12H, $\left.\operatorname{Ar}(o-\mathrm{Me})\right), 2.16$ (s, 6H, $\left.\operatorname{Ar}(p-\mathrm{Me})\right), 5.84(\mathrm{~s}, 2 \mathrm{H}, \operatorname{Im}(\mathrm{CH})), 6.62(\mathrm{~s}, 4 \mathrm{H}$, $\operatorname{Ar}(m-\mathrm{H})), 7.39$ (m, 3H, MgPh), 7.59 (m, 2H, MgPh); ${ }^{13} \mathrm{C}\left\{{ }^{1} \mathrm{H}\right\}$ NMR (125 MHz, $\left.\mathrm{C}_{6} \mathrm{D}_{5} \mathrm{Br}\right): 17.3$ (Ar(o-Me)), $20.8(\operatorname{Ar}(p-\mathrm{Me})), 121.8(\operatorname{Im}(\mathrm{CH})), 124.8(\mathrm{Ar}), 134.5(\mathrm{Ar}), 134.5(\mathrm{Ar}), 138.2(\mathrm{Ar})$, $139.8(\mathrm{Ar}), 167.0(\mathrm{Ar}), 181.9$ (carbene).

Preparation of $\left[\left\{(\mathbf{M g}(\mathrm{IMes})(\mathbf{B n})\}_{2}(\boldsymbol{\mu}-\mathbf{C l})_{2}\right](\mathbf{9})\right.$. Following the protocol 1 used for 7, 1.05 equiv. of benzylmagnesium chloride in $\mathrm{Et}_{2} \mathrm{O}$ solution $(1.1 \mathrm{ml}, 1.07 \mathrm{mmol})$ and 1 equiv. of free IMes $(0.310 \mathrm{~g}, 1.02 \mathrm{mmol})$ produced 9 as a white powder $(0.406 \mathrm{~g}, 82 \%) .{ }^{1} \mathrm{H}$ NMR $(500 \mathrm{MHz}$, $\left.\mathrm{C}_{6} \mathrm{D}_{5} \mathrm{Br}\right): 1.43$ (s, 2H, $\left.\mathrm{Bn}\left(\mathrm{CH}_{2}\right)\right), 1.89$ (s, 12H, $\operatorname{Ar}(o-\mathrm{Me})$ ), 2.13 (s, 6H, $\left.\operatorname{Ar}(p-\mathrm{Me})\right), 5.88$ (s, 2H, $\operatorname{Im}(\mathrm{CH})), 6.73(\mathrm{~s}, 4 \mathrm{H}, \operatorname{Ar}(m-\mathrm{H})), 6.90(\mathrm{t}, 1 \mathrm{H}, \mathrm{Bn}(p-\mathrm{CH})), 7.20(\mathrm{t}, 2 \mathrm{H}, \mathrm{Bn}(m-\mathrm{CH})), 7.25(\mathrm{~d}, 2 \mathrm{H}$, $\mathrm{Bn}(o-\mathrm{CH}) ;{ }^{13} \mathrm{C}\left\{{ }^{1} \mathrm{H}\right\}$ NMR (125 MHz, $\left.\mathrm{C}_{6} \mathrm{D}_{5} \mathrm{Br}\right): 17.4$ ( $\left.\mathrm{Ar}(o-\mathrm{Me})\right), 21.0(\mathrm{Ar}(p-\mathrm{Me})), 63.4(\mathrm{Bn})$, $122.2(\operatorname{Im}(\mathrm{CH})), 124.7$ (Ar), 126.7 (Ar), 129.1 (Ar), 134.6 (Ar), 134.7 (Ar), 138.0 (Ar), 146.7 (Ar), 182.9 (carbene).

Preparation of $\left[\left\{(\operatorname{Mg}(\operatorname{IPr})(\mathbf{P h})\}_{2}(\mu-\mathbf{B r})_{2}\right](\mathbf{1 0})\right.$. Following the protocol 1 used for 7, 1 equiv. of phenylmagnesium bromide in $\mathrm{Et}_{2} \mathrm{O}$ solution $(0.3 \mathrm{ml}, 0.80 \mathrm{mmol})$ and 1 equiv. of free $\operatorname{IPr}(0.312$ $\mathrm{g}, 0.80 \mathrm{mmol})$ produced 10 as a white powder $(0.298 \mathrm{~g}, 65 \%) .{ }^{1} \mathrm{H}$ NMR $\left(500 \mathrm{MHz}, \mathrm{C}_{6} \mathrm{D}_{5} \mathrm{Br}\right)$ : $1.09\left(\mathrm{~d},{ }^{3} \mathrm{~J}=6.6 \mathrm{~Hz}, 12 \mathrm{H}, \mathrm{CH}_{3}-i \mathrm{Pr}\right), 1.15\left(\mathrm{~d},{ }^{3} J=6.6 \mathrm{~Hz}, 12 \mathrm{H}, \mathrm{CH}_{3}-i \mathrm{Pr}\right), 2.62\left(\mathrm{sp},{ }^{3} J=6.6 \mathrm{~Hz}\right.$, 4H, CH-iPr), 7.26 (s, 2H, Im(CH)), $7.52\left(\mathrm{~d},{ }^{3} J=7.6 \mathrm{~Hz}, 4 \mathrm{H}, \operatorname{Ar}(m-\mathrm{H})\right), 7.60(\mathrm{~m}, 3 \mathrm{H}, \mathrm{MgPh}), 7.71$ $\left(\mathrm{t},{ }^{3} \mathrm{~J}=7.6 \mathrm{~Hz}, 2 \mathrm{H}, \operatorname{Ar}(p-\mathrm{H})\right), 8.02(\mathrm{~m}, 2 \mathrm{H}, \mathrm{MgPh})$.

Preparation of $\left[\left\{(\mathbf{M g}(\mathbf{I M e s})(\mathbf{B r})\}_{2}(\mu-\mathbf{C l})_{2}\right](\mathbf{1 1})\right.$. In a glovebox, 1.2 equiv. of ethylmagnesium bromide in $\mathrm{Et}_{2} \mathrm{O}$ solution $(0.70 \mathrm{ml}, 0.74 \mathrm{mmol})$ was added dropwise to a vigorously stirred slurry of 1.0 equiv. of IMesHCl $(0.211 \mathrm{~g}, 0.62 \mathrm{mmol})$ in $10 \mathrm{ml}$ of THF. Progressive dissolution of the imidazolium salt was observed simultaneously with formation of ethane bubbling. The resulting orange solution was stirred for $2 \mathrm{~h}$. Upon removal of the solvent under reduced pressure, a white powder was obtained and washed with $10 \mathrm{ml}$ of pentane, to afford the complex $11(0.274 \mathrm{~g}, 85$ 
\%). ${ }^{1} \mathrm{H}$ NMR (500 MHz, $d_{8}$-THF): 1.77 (m, 4H, THF), 2.16 (s, 12H, $\operatorname{Ar}(o-\mathrm{Me})$ ), 2.33 (s, 6H, $\operatorname{Ar}(p-\mathrm{Me})), 3.62(\mathrm{~m}, 4 \mathrm{H}, \mathrm{THF}), 7.02$ (s, 4H, $\operatorname{Ar}(m-\mathrm{H})), 7.31(\mathrm{~s}, 2 \mathrm{H}, \operatorname{Im}(\mathrm{H})) ;{ }^{13} \mathrm{C}\left\{{ }^{1} \mathrm{H}\right\}$ NMR $(125$ MHz, $d_{8}$-THF): $18.0(\operatorname{Ar}(o-\mathrm{Me})), 20.9$ ( $\left.\operatorname{Ar}(p-\mathrm{Me})\right), 26.2$ (THF), 68.0 (THF), $123.4(\operatorname{Im}(\mathrm{CH}))$, $129.5(\mathrm{Ar}(\mathrm{CH})), 136.3(\mathrm{Ar}), 136.3(\mathrm{Ar}), 139.4\left(\operatorname{Ar}\left(\mathrm{C}_{i p s o}\right)\right), 187.0$ (carbene).

Preparation of $\left[\mathrm{Mg}(\mathrm{IMes})(\mathrm{Me})(\mathbf{T H F})_{2}\right]^{+}\left[\left(\mathrm{B}_{\left(\mathrm{C}_{6}\right.} \mathrm{H}_{5}\right)_{4}\right]^{-}$(12). In a glovebox, 1 equiv. of $\mathrm{NaBPh}_{4}$ $(0.168 \mathrm{~g}, 0.56 \mathrm{mmol})$ and 5 equiv. of THF $(0.23 \mathrm{ml}, 2.8 \mathrm{mmol})$ were added to10 $\mathrm{ml}$ of fluorobenzene containing 1 equiv. of $[\mathrm{Mg}(\mathrm{IMes})(\mathrm{Me})(\mathrm{Br})(\mathrm{THF})](3)(0.280 \mathrm{~g}, 0.56 \mathrm{mmol})$. After 12 hours at room temperature, a precipitate was formed and the solvents were removed under reduced pressure. Three triturations/filtrations made with $10 \mathrm{ml}$ of pentane produced $\mathbf{1 2}$ as a white powder (0.414 g, 83\%). ${ }^{1} \mathrm{H}$ NMR (400 MHz, $\left.\mathrm{C}_{6} \mathrm{D}_{5} \mathrm{Br}\right):-1.62$ (s, 3H, MgMe), 1.18 (m, 8H, THF), 1.84 (s, 12H, $\operatorname{Ar}(o-\mathrm{Me})), 2.15$ (s, 6H, $\operatorname{Ar}(p-\mathrm{Me})), 2.88$ (m, 8H, THF), 6.74 (t, ${ }^{3} J=7.2 \mathrm{~Hz}$, 4H, BPh $(p-\mathrm{H})), 6.94\left(\mathrm{t},{ }^{3} J=7.4 \mathrm{~Hz}, 8 \mathrm{H}, \mathrm{BPh}(m-\mathrm{H})\right), 7.05(\mathrm{~s}, 4 \mathrm{H}, \operatorname{Ar}(m-\mathrm{H})), 7.15(\mathrm{~s}, 2 \mathrm{H}, \operatorname{Im}(\mathrm{H}))$, $7.33(\mathrm{~m}, 8 \mathrm{H}, \mathrm{BPh}(o-\mathrm{H})) ;{ }^{13} \mathrm{C}\left\{{ }^{1} \mathrm{H}\right\}$ NMR (125 MHz, $\left.\mathrm{C}_{6} \mathrm{D}_{5} \mathrm{Br}\right)-15.7$ (MgMe), 17.1 ( $\operatorname{Ar}(o-\mathrm{Me})$ ), 20.8 (THF), $24.1(\operatorname{Ar}(p-M e)), 69.4(\mathrm{THF}), 121.5(\mathrm{BPh}(\mathrm{CH})), 124.2(\operatorname{Im}(\mathrm{CH})), 125.4(\mathrm{~m}$, $\mathrm{BPh}(\mathrm{CH})), 129.7(\mathrm{Ar}(\mathrm{CH})), 135.9(\mathrm{Ar}), 136.2(\mathrm{Ar}), 136.8(\mathrm{BPh}(\mathrm{CH})), 139.9\left(\operatorname{Ar}\left(\mathrm{C}_{i p s o}\right)\right), 164.8$ $\left(\mathrm{m}, \mathrm{BPh}\left(\mathrm{C}_{i p s o}\right)\right), 179.1$ (carbene); ${ }^{11} \mathrm{~B}$ NMR $\left(128 \mathrm{MHz}, \mathrm{C}_{6} \mathrm{D}_{5} \mathrm{Br}\right)-5.9\left(\mathrm{BPh}_{4}\right)$.

Preparation of $\left[\mathrm{Mg}(\operatorname{IPr})(\mathrm{Me})(\mathrm{THF})_{2}\right]^{+}\left[\left(\mathrm{B}\left(\mathrm{C}_{6} \mathrm{H}_{5}\right)_{4}\right)^{-1}\right.$ (13). Following a protocol used for 12, 1 equiv. of $\mathrm{NaBPh}_{4}(0.180 \mathrm{~g}, 0.54 \mathrm{mmol}), 5$ equiv. of THF $(0.21 \mathrm{ml}, 2.7 \mathrm{mmol})$ and 1 equiv. of $[\mathrm{Mg}(\mathrm{IPr})(\mathrm{Me})(\mathrm{Br})(\mathrm{THF})](\mathbf{5})(0.300 \mathrm{~g}, 0.54 \mathrm{mmol})$ produced 13, as a white powder $(0.389 \mathrm{~g}, 81$ \%). ${ }^{1} \mathrm{H}$ NMR (500 MHz, $\left.\mathrm{C}_{6} \mathrm{D}_{5} \mathrm{Br}\right):-1.70(\mathrm{~m}, 2 \mathrm{H}, \mathrm{MgMe}), 1.00\left(\mathrm{~d},{ }^{3} \mathrm{~J}=6.6 \mathrm{~Hz}, 12 \mathrm{H}, \mathrm{CH}_{3}-i \mathrm{Pr}\right.$ ), $1.12\left(\mathrm{~d},{ }^{3} J=6.6 \mathrm{~Hz}, 12 \mathrm{H}, \mathrm{CH}_{3}-i \operatorname{Pr}\right), 1.19$ (m, 8H, THF), 2.48 (sp, ${ }^{3} J=6.6 \mathrm{~Hz}, 4 \mathrm{H}, \mathrm{CH}-i \mathrm{Pr}$ ), 2.85 (m, 8H, THF), $6.75(\mathrm{~s}, 2 \mathrm{H}, \operatorname{Im}(\mathrm{H})), 6.96\left(\mathrm{t},{ }^{3} J=7.1 \mathrm{~Hz}, 4 \mathrm{H}, \mathrm{BPh}(p-\mathrm{H})\right), 7.13\left(\mathrm{t},{ }^{3} J=7.4 \mathrm{~Hz}, 8 \mathrm{H}\right.$, $\operatorname{BPh}(m-\mathrm{H})), 7.31\left(\mathrm{~d},{ }^{3} J=7.7 \mathrm{~Hz}, 4 \mathrm{H}, \operatorname{Ar}(m-\mathrm{H})\right), 7.42\left(\mathrm{t},{ }^{3} J=7.7 \mathrm{~Hz}, 2 \mathrm{H}, \operatorname{Ar}(p-\mathrm{H})\right), 7.78(\mathrm{~m}, 8 \mathrm{H}$, $\operatorname{BPh}(o-\mathrm{H})) ;{ }^{13} \mathrm{C}$ NMR (125 MHz, $\left.\mathrm{C}_{6} \mathrm{D}_{5} \mathrm{Br}\right)$ : -15.9 (MgMe), 22.3 (THF), $23.8\left(\mathrm{CH}_{3}-i \mathrm{Pr}\right), 29.0$ (CH-iPr), 69.2 (THF), $121.5(\mathrm{BPh}(\mathrm{CH})), 124.2(\mathrm{Im}(\mathrm{CH})), 124.4(\mathrm{Ar}(\mathrm{CH})), 125.4(\mathrm{~m}, \mathrm{BPh}(\mathrm{CH}))$, $130.1(\operatorname{Ar}(\mathrm{CH})), 136.8(\mathrm{BPh}(\mathrm{CH})), 137.4(\mathrm{Ar}), 146.5\left(\operatorname{Ar}\left(\mathrm{C}_{i p s o}\right)\right) 164.4\left(\mathrm{~m}, \mathrm{BPh}\left(\mathrm{C}_{i p s o}\right)\right), 181.6$ (carbene); ${ }^{11} \mathrm{~B}$ NMR $\left(128 \mathrm{MHz}, \mathrm{C}_{6} \mathrm{D}_{5} \mathrm{Br}\right)-5.9\left(\mathrm{BPh}_{4}\right)$. 
Preparation of $\left.\left[\{[\mathrm{Mg}(\mathrm{IMes})(\mathrm{Me})][\mathrm{Mg}(\mathrm{IMes})]\}(\mu-\mathrm{Me})_{2}\right]_{2}(\mu-\mathrm{Br})_{2}\right]^{2+}\left[\left(\mathbf{B}\left(\mathrm{C}_{6} \mathbf{F}_{5}\right)_{4}\right]_{2} \quad\right.$ (14). In a glovebox, 1 equiv. of $\mathrm{Li}\left[\mathrm{B}\left(\mathrm{C}_{6} \mathrm{~F}_{5}\right)_{4}\right](0.123 \mathrm{~g}, 0.18 \mathrm{mmol})$ was added to $10 \mathrm{ml}$ of bromobenzene containing 1 equiv. of $\left[\left\{(\mathrm{Mg}(\mathrm{IMes})(\mathrm{Br})\}_{2}(\mu-\mathrm{Me})_{2}\right](7)(0.087 \mathrm{~g}, 0.09 \mathrm{mmol})\right.$. A white precipitate was immediately observed upon addition of the sodium salt. After filtration over Kieselguhr, the resulting solution was cooled at $-35{ }^{\circ} \mathrm{C}$ providing 14 as colourless crystals. $(0.063 \mathrm{~g}, 22 \%) .{ }^{1} \mathrm{H}$ NMR (400 MHz, $\left.\mathrm{C}_{6} \mathrm{D}_{5} \mathrm{Br}\right):-2.63$ (s, 3H, MgMe), 1.82 (s, 24H, $\operatorname{Ar}(o-\mathrm{Me})$ ), 2.20 (s, 12H, $\operatorname{Ar}(p-$ $\mathrm{Me})$ ), 6.62 (s, 4H, $\operatorname{Im}(\mathrm{H})), 6.71$ (s, 4H, Mes), 6.79 (s, 8H, Mes); ${ }^{13} \mathrm{C}\left\{{ }^{1} \mathrm{H}\right\}$ NMR (125 MHz, $\left.\mathrm{C}_{6} \mathrm{D}_{5} \mathrm{Br}\right)$-16.9 (MgMe), 16.7 ( $\mathrm{Ar}(o-\mathrm{Me})$ ), 20.6 ( $\mathrm{Ar}(p-\mathrm{Me})$ ), 127.7 (Ar), 137.3 (Ar), $139.0(\mathrm{Ar})$, 141.8 (Ar), 142.7 (Ar), 148.8 (Ar), 175.3 (carbene).

\section{Associated content}

\section{Supporting information}

NMR spectra of complexes 1-14, summary of crystal data for $5,6,7,8,9,10,11,12,13$, computational details on models V', VI, VII, XII' and XIII. The Crystallographic information files (CIF) have been deposited with the CCDC, 12 Union Road, Cambridge, CB2 1EZ, U.K., and can be obtained on request free of charge, by quoting the publication citation and deposition numbers 1906336 \& 1906341-1906349. This material is also available free of charge via the Internet at http://pubs.acs.org.

\section{Author information}

\section{Corresponding Authors}

*E-mail: dagorne@unistra.fr; defremont@unistra.fr

\section{ORCID}

Samuel Dagorne: 0000-0001-7393-286X

Pierre de Frémont: 0000-0001-8470-3659

Lydia Karmazin : 0000-0003-0416-6190

Laurent Ruhlmann: 0000-0003-1154-2422 


\section{Acknowledgment}

The Centre National de la Recherche Scientifique (CNRS), The University of Strasbourg and the Ministère de l'Enseignement Supérieur et de la Recherche (Ph.D. fellowship to J.C.B) are gratefully acknowledged for support. The NMR service of the Universite de Strasbourg is warmly acknowledged for the various studies.

\section{Notes}

The authors declare no competing financial interest.

\section{References}

1. Grignard, V. Sur quelques nouvelles combinaisons organométalliques du magnésium et leur application à des synthèses d'alcools et d'hydrocarbures. C. R. Hebd. Séances Acad. Sci. 1900, $1322-1325$.

2. The Chemistry of Organomagnesium Compounds, Eds. : Rappoport, Z.; Marek, I.; WileyVCH, Weinheim, 2008.

3. Seyferth, D. The Grignard Reagents. Organometallics 2009, 28, 1598-1605.

4. Selected reviews/books on NHCs: (a) N-Heterocyclic Carbenes: Effective Tools in Organometallic Synthesis, Ed.: Nolan, S. P.; Wiley-VCH,Weinheim, 2014. (b) Bourissou, D.; Guerret, O.; Gabbaï, F.; Bertrand, G. Stable Carbenes Chem. Rev. 2000, 100, 39-92. c) W. A. Herrmann $N$ - Heterocyclic Carbenes: A New Concept in Organometallic Catalysis. Angew. Chem. Int. Ed. 2002, 41, 1290-1309. d) César, V.; Bellemin-Laponnaz, S.; Gade, L. H. Chiral Nheterocyclic carbenes as stereodirecting ligands in asymmetric catalysis. Chem. Soc. Rev. 2004, 
33, 619; e) de Frémont, P.; Marion, N.; Nolan, S. P. Carbenes: Synthesis, Properties, and Organometallic Chemistry. Coord. Chem. Rev. 2009, 253, 862-892. (f) Fliedel, C.; Schnee, G.; Avilés, T.; Dagorne, S. Group 13 metal (Al, Ga, In, Tl) complexes supported by heteroatombonded carbene ligands. Coord. Chem. Rev. 2014, 275, 63-86.

5. Bellemin-Laponnaz, S.; Dagorne, S. Group 1 and 2 and Early Transition Metal Complexes Bearing N-Heterocyclic Carbene Ligands: Coordination Chemistry, Reactivity, and Applications Chem. Rev. 2014, 114, 8747-8774.

6. Nesterov, V.; Reiter, D.; Bag, P.; Frisch, P.; Holzner, R.; Porzelt, A.; Inoue, S. NHCs in Main Group Chemistry. Chem. Rev. 2018, 118, 9678-9842.

7. Arduengo, A. J.; Dias, H. V. R.; Davidson, F.; Harlow, R. L. Carbene Adducts of Magnesium and Zinc. J. Organomet. Chem. 1993, 462, 13-18.

8. Selected representative examples of NHC-Mg species: (a) Arduengo, A. J.; Davidson, F.; Krafczyk, R.; Marshall, W. J.; Tamm, M. Adducts of Carbenes with Group II and XII Metallocenes ${ }^{\dagger}$. Organometallics 1998, 17, 3375-3382. (b) Mungur, S. A.; Liddle, S. T.; Wilson, C.; Sarsfield, M. J.; Arnold, P. L. Bent metal carbene geometries in amido N-heterocyclic carbene complexes. Chem. Commun. 2004, 23, 2738-2739. (c) Zhang, D.; Kawaguchi, H. Deprotonation Attempts on Imidazolium Salt Tethered by Substituted Phenol and Construction of Its Magnesium Complex by Transmetalation. Organometallics 2006, 25, 5506-5509. (d) Kennedy, A. R.; Klett, J.; Mulvey, R. E.; Robertson, S. D. N-Heterocyclic-Carbene-Induced Monomerization of Sterically Encumbered Dialkylmagnesium and Dialkylmanganese Polymers. Eur. J. Inorg. Chem. 2011, 2011, 4675-4679. (e) Arrowsmith, M.; Hill, M. S.; MacDougall, D. J.; Mahon, M. F. A Hydride-Rich Magnesium Cluster. Angew. Chem. Int. Ed. 2009, 48, 40134016. (f) Ghadwal, R. S.; Rottschäfer, D.; Schürmann, C. J. Expedient Access to Normal- and Abnormal- N-Heterocyclic Carbene (NHC) Magnesium Compounds from Imidazolium Salts: Expedient Access to Normal- and Abnormal- N-Heterocyclic Carbene (NHC) Magnesium Compounds from Imidazolium Salts. Z. Für Anorg. Allg. Chem. 2016, 642, 1236-1240. (g) 
Baishya, A.; Peddarao, T.; Nembenna, S. Organomagnesium Amide Catalyzed CrossDehydrocoupling of Organosilanes with Amines. Dalton Trans. 2017, 46, 5880-5887. (h) Wong, Y. O.; Freeman, L. A.; Agakidou, A. D.; Dickie, D. A.; Webster, C. E.; Gilliard Jr., R. J. Two Carbenes versus One in Magnesium Chemistry: Synthesis of Terminal Dihalide, Dialkyl, and Grignard Reagents. Organometallics 2019, 38, 688-696. (i) Kennedy, A. R.; Mulvey, R. E.; Robertson, S. D. N-Heterocyclic Carbene Stabilized Adducts of Alkyl Magnesium Amide, Bisalkyl Magnesium and Grignard Reagents: Trapping Oligomeric Organo s-Block Fragments with NHCs. Dalton Trans. 2010, 39, 9091-9099.

9. For use of Mg-NHC complexes in catalysis, see: (a) Arnold, P. L.; Casely, I. J.; Turner, Z. R.; Bellabarba, R.; Tooze, R. B. Magnesium and Zinc Complexes of Functionalised, Saturated NHeterocyclic Carbene Ligands: Carbene Lability and Functionalisation, and Lactide Polymerisation Catalysis. Dalton Trans. 2009, 7236-7247. (b) Antu, B.; Manohar Pawar, G.; Wurst, K.; Decker, U.; Schmidt, A. M.; Buchmeiser, M. R. $\mathrm{CO}_{2}$, Magnesium, Aluminum, and Zinc Adducts of N-Heterocyclic Carbenes as (Latent) Catalysts for Polyurethane Synthesis. Eur. J. Inorg. Chem. 2009, 1970-1976. (c) Okamoto, S.; Ishikawa, H.; Shibata, Y.; Suhara, Y. Grignard Allylic Substitution Catalyzed by Imidazol-2-Ylidene- and Imidazol-4-YlideneMagnesium Complexes. Tetrahedron Lett. 2010, 51, 5704-5707. (b) Baishya, A.; Barman, M. K.; Peddarao, T.; Nembenna, S. Catalytic C-N Bond Formation in Guanylation Reaction by NHeterocyclic Carbene Supported Magnesium(II) and Zinc(II) Amide Complexes. J. Organomet. Chem. 2014, 769, 112-118.

10. Recent representative examples of discrete $\mathrm{Mg}$ species in catalysis: (a) Rauch, M.; Ruccolo, S.; Parkin, G. Synthesis, Structure, andReactivity of a Terminal Magnesium Hydride Compound with a Carbatrane Motif, [TismPriBenz]MgH: A Multifunctional Catalyst for Hydrosilylation and Hydroboration. J. Am. Chem. Soc. 2017, 139, 13264-13267. (b) Anker, M. D.; Arrowsmith, M.; Bellham, P.; Hill, M. S.; Kociok-Köhn, G.; Liptrot, D. J.; Mahon, M. F.; Weetman, C. Selective reduction of $\mathrm{CO}_{2}$ to a methanol equivalent by $\mathrm{B}\left(\mathrm{C}_{6} \mathrm{~F}_{5}\right)_{3}$-activated alkaline earth catalysis. Chem. Sci. 2015, 5, 2826-2830. (c) Lampland, N. L.; Pindwal, A.; Neal, S. R.; Schlauderaff, S.; Ellern, A.; Sadow, A. D. Magnesium-catalyzed hydrosilylation of $\alpha, \beta$-unsaturated esters. Chem. Sci. 2015, 6, 6901-6907. (d) Bellham, P.; Hill, M. S.; Kociok-Köhn, G.; Liptrot, D. J. Bespoke 
synthesis of unsymmetrical diaminoboranes by alkaline earth catalysis. Chem. Commun. 2013, 49, 1960-1962. (e) Baishya, A; Kumar, L.; Barman, M. Kr.; Biswal, H. S.; Nembenna, S. NHeterocyclic Carbene-Carbodiimide ("NHC-CDI") Adduct or Zwitterionic-Type Neutral Amidinate-Supported Magnesium(II) and Zinc(II) Complexes Inorg. Chem. 2017, 56, 95359546.

11. Review: Hill, M. S.; Liptrot, D. J.; Weetman, C. Alkaline earths as main group reagents in molecular catalysis. Chem. Soc. Rev. 2016, 45, 972-988.

12. Selected cationic Mg(II) complexes: (a) Juergen, P. ; Stennett, T. E.; Volland, M.; Guldi, D. M.; Harder, S. Complexation and Versatile Reactivity of a Highly Lewis Acidic Cationic Mg Complex with Alkynes and Phosphines. Chem. Eur. J. 2019, 25, 2025-2034. (b) Friedrich, A.; Pahl, J.; Elsen, H.; Harder, S. Bulky cationic $\beta$-diketiminate magnesium complexes. Dalton Trans. 2019, 48, 5560-5568. (c) Pahl, J.; Friedrich, A.; Elsen, H.; Harder, S. Cationic Magnesium $\pi$-Arene Complexes Organometallics 2018, 37, 2901-2909. (d) Pahl, J.; Brand, S.; Elsen, H.; Harder, S. Highly Lewis acidic cationic alkaline earth metal complexes Chem. Commun. 2018, 54, 8685-8688. (e) Rauch, M.; Parkin, G. Zinc and Magnesium Catalysts for the Hydrosilylation of Carbon Dioxide J. Am. Chem. Soc. 2017, 139, 18162-18165. (f) Wheaton, C. A.; Hayes, P. G. Designing cationic zinc and magnesium catalysts for coordination-insertion polymerization of lactide Comments Inorg. Chem. 2011, 32, 127-162. (g) Sarazin, Y.; Schormann, M.; Bochmann, M. Novel Zinc and Magnesium Alkyl and Amido Cations for RingOpening Polymerization Reactions. Organometallics 2004, 23, 3296-3302.

13. (a) Specklin, D.; Hild, F.; Fliedel, C.; Gourlaouen, C.; Veiros, L. F.; Dagorne, S. Accessing Two-coordinate Zn(II) Organocations by NHC coordination: Synthesis, Structure, and Use as $\pi$ Lewis acids in alkene, alkyne and $\mathrm{CO}_{2}$ hydrosilylation. Chem. Eur. J. 2017, 23, 15908-15912. (b) Specklin, D.; Fliedel, C.; Gourlaouen, C.; Bruyere, J.-C.; Avilés, T.; Boudon, C.; Ruhlmann, L.; Dagorne, S. N-Heterocyclic Carbene Based Tri-organyl-Zn-Alkyl Cations: Synthesis, Structures, and Use in $\mathrm{CO}_{2}$ Functionalization Chem. Eur. J. 2017, 23, 5509-5519. 
14. Mantina, M.; Chamberlin, A.C.; Valero, R.; Cramer, C. J.; Truhlar, D. G. Consistent van der Waals Radii for the Whole Main Group. J. Phys. Chem. A 2009, 113, 5806-5812.

15. Stasch, A.; Jones, C. Stable dimeric magnesium(I) compounds: from chemical landmarks to versatile reagents. Dalton Trans. 2011, 40, 5659.

16. Tapu, D.; Dixon, D. A.; Roe, C. ${ }^{13} \mathrm{C}$ NMR Spectroscopy of "Arduengo-type" Carbenes and Their Derivatives. Chem. Rev. 2009, 109, 3385-3407.

17. (a) Green, S. P.; Jones, C.; Stasch, A. Stable Adducts of a Dimeric Magnesium(I) Compound. Angew. Chem. Int. Ed. 2008, 47, 9079-9083; (b) Bonyhady, S. J.; Jones, C.; Nembenna, S.; Stasch A.; Edwards, A. J.; McIntyre, G. J. $\beta$-Diketiminate-Stabilized Magnesium(I) Dimers and Magnesium (II) Hydride Complexes: Synthesis, Characterization, Adduct Formation, and Reactivity Studies. Chem. Eur. J. 2010, 16, 938-955.

18. Michalczyk, M. J. Synthesis of magnesium hydride by the reaction of phenylsilane and dibutylmagnesium Organometallics 1992, 11, 2307-2309.

19. Perdew, J. P.; Burke, K.; Ernzerhof, M. Generalized Gradient Approximation Made Simple. Phys. Rev. Lett. 1996, 77, 3865-68.

20. Ditchfield, R.; Hehre, W. J.; Pople, J. A. Self- Consistent Molecular- Orbital Methods. IX. An Extended Gaussian- Type Basis for Molecular- Orbital Studies of Organic Molecules. J. Chem. Phys. 1971, 54, 724-728.

21. For shorter calculation time, for larger models V, VII and XII', single points were performed on simplified structures with the replacement of N-Dipp/N-Mes substituents by N-Me.

22. (a) Arduengo III, A. J.; Dias, H. V. R.; Harlow, R. L.; Kline, M. Electronic stabilization of nucleophilic carbenes. J. Am. Chem. Soc. 1992, 114, 5530. (b) Jafarpour, L.; Stevens, E. D.; Nolan, S. P. A sterically demanding nucleophilic carbene: 1,3-bis(2,6- 
diisopropylphenyl)imidazol-2-ylidene). Thermochemistry and catalytic application in olefin metathesis. J. Organomet. Chem. 2000, 606, 49.

23. Sheldrick, G. M. A Short History of SHELX. Acta Crystallogr. A 2008, 64, 112-122.

24. Sheldrick, G. M. SHELXT - Integrated space-group and crystal-structure determination. Acta Cryst. A 2015, 71, 3-8. 